\title{
A 20 year forecast of water usage in electricity generation for South Africa amidst water scarce
}

conditions

\author{
George Alex Thopil ${ }^{\mathrm{a}}$, Anastassios Pouris ${ }^{\mathrm{b}}$
}

\author{
${ }^{a}$ Department of Engineering and Technology Management, University of Pretoria, South Africa \\ ${ }^{b}$ Institute for Technological Innovation, University of Pretoria, South Africa
}

\begin{abstract}
Being a semi-arid country with limited fresh water resources and also a fossil fuel based energy intensive country, South Africa encounters the added pressure of allocating limited water resources. Roughly $90 \%$ of electricity in South Africa is generated from coal fired power plants that are located in semi-arid areas and use a combination of wet and dry cooling techniques. The paper aims to forecast water usage within coal based electricity generation in order to facilitate water management in water deficient parts of the country. Some of the older return to service (RTS) power plants which have been brought back to operation due to electricity shortages are water intensive and are located in water constrained water management areas. These power plants should be phased out gradually and replaced by higher efficiency dry cooled power plants - that are currently under construction - by the year 2020. Total water requirements could reach 370 gigalitres by the year 2021 from current levels of 360 gigalitres. Depending on the retirement of inefficient power plants, total water usage can be reduced by roughly $14 \%$. Results show that management of water resources in the electricity generation sector can result in informed water allocations within water management areas. Proposed gradual retirement of the RTS fleet could result in a savings of $15 \%$ of the forecasted shortfall of 234 gigalitres by the year 2025. The deficit in electricity generation output caused by the retirement of the RTS fleet will have to be compensated by the simultaneous commissioning and operation of new build power plants. Such measures will provide much required water relief to water constrained water management areas. Overall increases in water usage until 2035 can be minimised if inefficient wet cooled power plants are gradually retired and if dry cooled power plants are more prominent.
\end{abstract}

Keywords:

Water, forecasting, South Africa, electricity, cooling

$\begin{array}{ll}\text { Nomenclature } & \\ \text { CSP } & \text { Concentrating solar power } \\ \text { EIA } & \text { Energy Information Administration } \\ \text { EPRI } & \text { Electric Power Research Institute } \\ \text { FBC } & \text { Fluidised Bed Combustion } \\ \text { FGD } & \text { Flue gas desulfurization } \\ \text { GDP } & \text { Gross Domestic Product } \\ \text { Gigalitre } & 1000000 \mathrm{~m}^{3} \\ \text { GWh } & \text { Gigawatt-hour }\end{array}$




$\begin{array}{ll}\text { kWh } & \text { kilowatt-hour } \\ \text { Megalitre } & 1000 \mathrm{~m}^{3} \\ \mathrm{Mm} / \mathrm{yr} & \text { millimetre per year } \\ \mathrm{Mm} / \text { annum } & \text { millimetre per annum } \\ \mathrm{NETL} & \text { National Energy Technology Laboratory } \\ \mathrm{PF} & \text { Pulverised Fuel } \\ \text { RTS } & \text { Return to service } \\ \text { TWh } & \text { Terawatt-hour } \\ \text { UGC } & \text { Underground Coal Gasification } \\ \text { USGS } & \text { United States Geological Survey } \\ \text { WMA } & \text { Water management area }\end{array}$

\section{Introduction}

\subsection{Background}

Scarcity of water is a broad issue that is a concern for national governments and policy making bodies the world over. More than 1 billion people currently lack access to safe drinking water, and 2.4 billion people lack access to improved sanitation [1]. It is estimated that by 2025 , more than $60 \%$ of the world's population will live in countries with significant imbalances between water requirements and supplies, largely in Asia, Africa, and Latin America [2]. Water imbalances have therefore led to increased attention to the allocation and utilisation of water within the water-energy nexus in these regions [3], [4], [5], [6].

Currently water usage forecasts do not exist for the South African electricity sector. This article aims to forecast water consumption associated with coal based electricity generation in South Africa up to the year 2035. These type of forecasts are used by the electricity producing utilities and by the water related authorities for planning purposes internationally. The paper provides water usage forecasts based on power plant categories and cooling technology type thereby facilitating the identification of the impact of the various power plant categories and cooling technologies on water needs. The approach is facilitated by the fact that South Africa is one of the few countries in the world that have available detailed water use data per power station. These estimates are critical because roughly $90 \%$ of South Africa's power is generated from coal power plants which are located in semi-arid areas. The research is also relevant for countries that are fossil-fuel dependent and lack abundant fresh water resources.

South Africa is located in a semi-arid region and considered among one of the 30 driest countries in the world. South Africa could face a situation of extensive water scarcity unless current reserves and usage patterns are managed properly [7]. These assessments are given further weight when considering the fact that South Africa's mean annual precipitation is $497 \mathrm{~mm} / \mathrm{yr}$, which is well below the global average of 860 $\mathrm{mm} /$ annum [8]. Putting things further into perspective, Botswana and Namibia have an annual rainfall of $400 \mathrm{~mm} / \mathrm{yr}$ and $254 \mathrm{~mm} / \mathrm{yr}$ respectively, but have populations of only 2,00 and 2,28 million, while South Africa has a population of 50 million people [9]. To add to this, South Africa's relatively low rainfall rate and large population size place a skewed level of stress on the limited water resources. South Africa has no extensive or navigable rivers, with the Zambezi River being the closest fitting these characteristics. The rivers in South Africa, namely the Limpopo, Inkomati, Pongola and Orange, have a combined annual flow of 
49000 cubic metres per year $\left(\mathrm{m}^{3} / \mathrm{a}\right)$, which is less than half of the Zambezi's, which highlights South Africa's limited water availability when compared to neighbouring regions [10]. The hard rock nature of the country's geology allows only about $20 \%$ of the groundwater resources' major aquifer systems to be available for utilisation on a large scale.

As a result of the presence of minerals and resources in areas devoid of major water sources, urban populations in regions (such as Gauteng and Mpumalanga Highveld) have increased and led to a skewed supply-demand scenario.

To facilitate water management the country has been divided into 19 catchment-based water management areas (WMA). The inter-linking of these areas plays a major role in catering to country's needs and preventing disparity of water supply. Of the 19 WMAs, water requirements exceeded availability in 15 catchment areas [10]. The province of Gauteng in particular is expected to suffer shortages in the future. However, cooperation with the Lesotho government through the Lesotho Highlands Project is expected to ease shortages in the Province [11].

The South African situation is not unique in the world. A similar situation of natural misallocation of water resources has also been observed in China, with the north of the country facing severe shortages compared to the south. China's economy is similar to South Africa's from the perspective of the agricultural sector's water usage to GDP contribution. China's agricultural sector uses $65 \%$ of water resources, while contributing to less than $15 \%$ of the GDP [12]. South Africa, similarly, utilises $66 \%$ of the water resources to generate $3 \%$ of the GDP [13]. While restructuring of the economy may alleviate some of the water challenges another possible major cause of scarcity of water may be related to climate change. From a subSaharan and South African perspective, the projections portray a negative picture, with rainfall expected to decrease by $50 \%$ [14].

\subsection{Water usage in South Africa}

The majority of water resources (62\%) in South Africa is used for agriculture and irrigation. Rural and urban use accounts for $18 \%$ and usage by large industries and power generation accounts for $8 \%$ [15]. Similar patterns can be observed in the sectoral water usage breakdown provided in the second National Water Resource Strategy [13]. Of the 19 WMAs, 9 encounter moderate shortages whereas 6 WMAs face severe shortage (as shown in Figure 1). Though water usage in power generation and large industries is approximately only $8 \%$, the regions where these industries are located in moderately to severely water constrained WMAs [16]. The national accounts database related to WMAs published by Statistics South Africa, anticipate a base case water deficit of 234 gigalitres by the year 2025 [17]. Therefore, informed water usage within the power generation sector could ease the water burden in the severely and moderately constrained WMAs. 


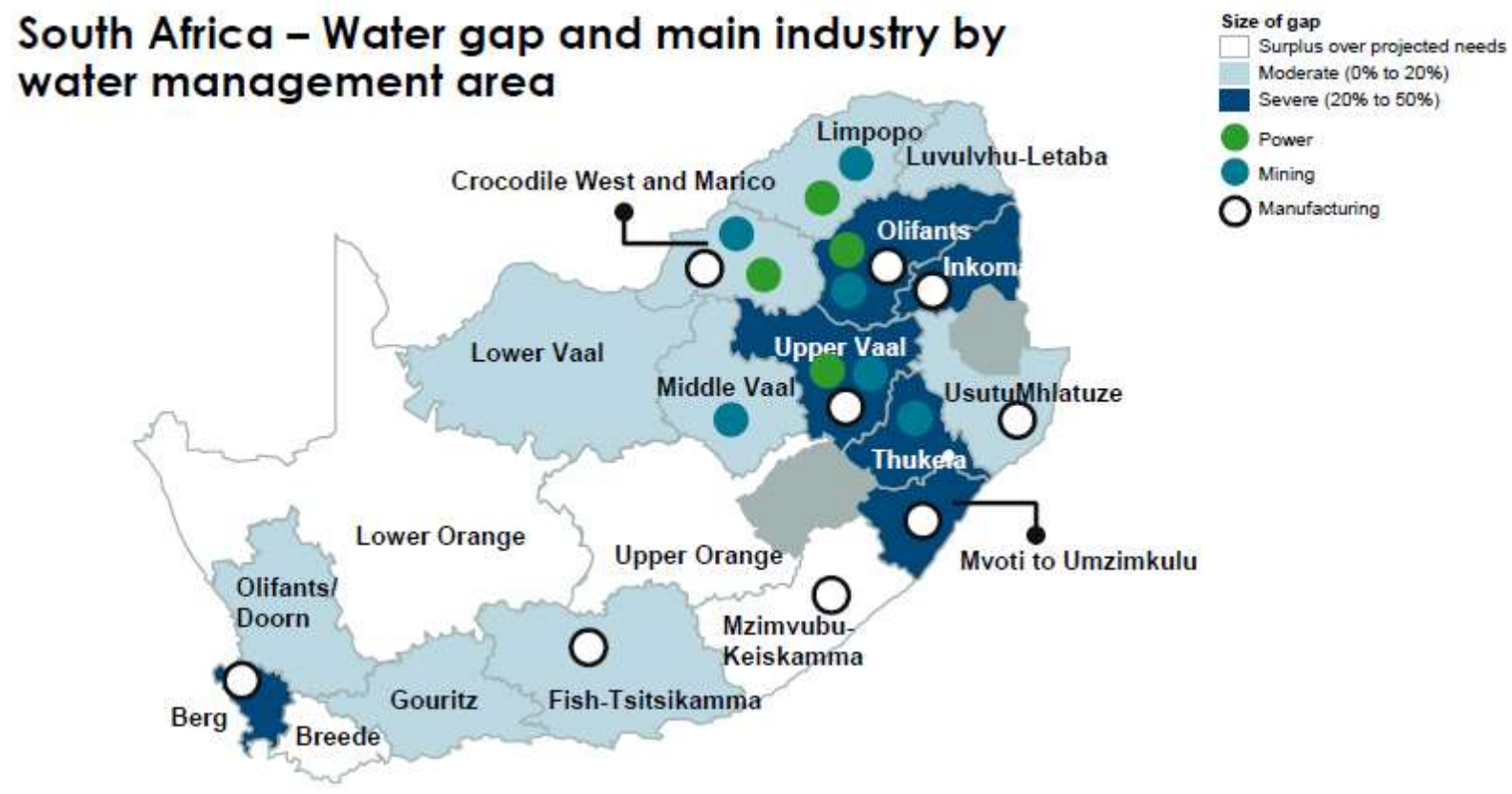

Figure 1: South Africa water management area gaps [16]

The World Bank databank provides data for South African sectoral water withdrawal for the year 2011 (shown in Figure 2). The focus of this study is to analyse the usage of water for electric power generation. The field of integrated water-energy studies was established in 1994 by Peter Gleick with his Annual Review of Energy and the Environment article. Gleick [18] employed a life cycle analysis of water and energy resources to explain and quantify the water intensity of energy resource development from extraction through power generation, as well as the energy intensity of the water sector from extraction through conveyance, treatment, distribution and end use. Despite the importance of the field for policy and planning "the depth of Gleick's call for regulatory and operational innovation, and for more interdisciplinary research to capture the full benefits of integrated water-energy resource management, largely remains unmet" [19].

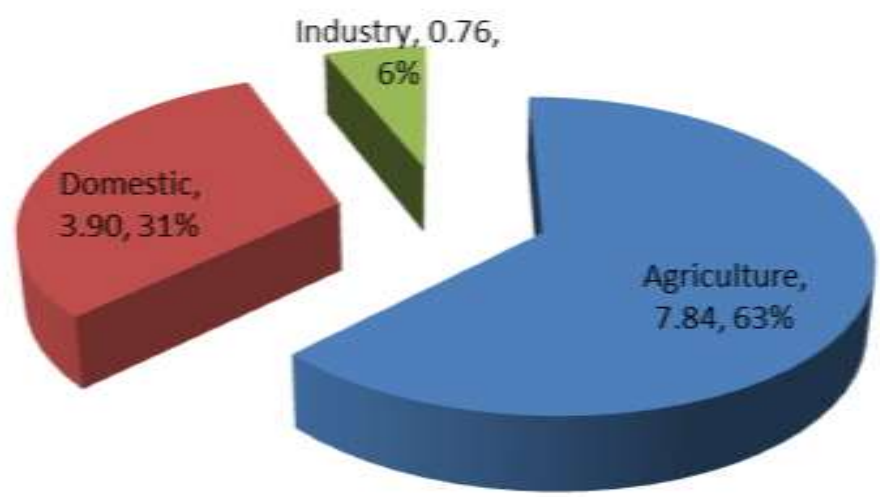

Figure 2: Water withdrawal in South Africa (2011 billion cubic metres) [20] 
Water for electricity is of particular importance as thermoelectric power plants are among the most voracious users of water. In the United States the Geological Survey estimated that in 2005 the thermoelectric power plants were responsible for nearly $52 \%$ of surface freshwater withdrawals and $43 \%$ of total water withdrawals [21]. Power plants only consume $7 \%$ in once-through cooling technology while consuming $70 \%$ in closed loop (wet) cooling respectively (and returning the rest to the environment). $43 \%$ of the generating capacity is associated with once-through cooling while $42 \%$ uses wet closed loop cooling (Feeley et al., 2008). To put it into perspective thermoelectric withdrawals were 200 billion gallons $^{1}$ a day or 670 gallons per U.S. inhabitant [19].

According to Kenny et al. [21] of the U.S. Geological Survey "withdrawal" is defined as the amount of water removed from the ground or diverted from a water source for use, while "consumption" refers to the amount of water that is evaporated, transpired, incorporated into products or crops or otherwise removed from the immediate water environment.

In other words water withdrawn is distinguished from water consumption under the logic that water that is withdrawn from a source can be returned to that source. However, if the water withdrawn from a source is not returned to the source, the water usage is categorised as consumption. Different sectors have dissimilar water withdrawal and consumption rates. The technologies used in different sectors also affect the withdrawal and consumption rates. The focus in this investigation is water usage patterns of the multiple power coal (thermal) power plants in South Africa. Depending on the cooling technologies in use, power plants tend to have different water withdrawal and consumption rates

The paper therefore aims to forecast water usage patterns associated with coal based electricity generation based on water consumption factors (in $\mathrm{l} / \mathrm{kWh}$ ) and total water consumption (in megalitres and gigalitres). The paper also aims to assess scenarios of water usage patterns based on cooling technology and power plant type; and assess water usage patterns for wet cooled and dry cooled power plants. Assessment is also performed based on load type for base load and non-base load power plants. Based on water consumption patterns the paper aims to identify water distressed water management areas where the power plants are located.

The following section constitutes the literature review which describes certain key technologies in the field of energy- water nexus, provides a review of relevant literature and refers to efforts to forecast water demand for electricity generation. Section 3 outlines the methodology followed in this effort and section 4 provides the results of the investigation. Section 5 discusses the main findings of the analysis and the strengths and shortcomings. The final section provides conclusions, implications and recommendations for further research.

\section{Literature review}

Over the past few decades the evolution of technologies has resulted in countries employing a combination of mechanisms to operate thermal power plants [22]. The first part of this section will introduce a number of cooling technologies that are used internationally. The second section provides a discussion of the

\footnotetext{
${ }^{1}$ Please note billion in this report refers to short billion. 1 US gallon $=3.785$ litres
} 
consumption of water occurring within diverse electricity generation technologies. The combination of cooling technology and fuel technology tends to alter the water demand in electricity generation drastically. Therefore water demand forecasting is essential in determining the contribution of electricity generation within the overall water usage profile of a country or region. Having discussed the relevant topics in chronological order the South African electricity generation profile and thermal power plant cooling technologies are introduced and discussed.

\subsection{Water usage technologies}

This section elaborates on the concepts often referred in investigating water use at power plants. The concepts of water withdrawal, water consumption and the various types of cooling systems are part of these issues. It should be emphasised that water is also used for non-cooling plant processes such as for operation of flue gas desulfurization (FGD) devices, ash handling, wastewater treatment, and wash water. However, cooling water usage is by at least one order of magnitude larger than the other uses [23].

Water use for cooling of thermoelectric power plants is affecting the overall water supply and the ecological health of surface water bodies [23]. In a number of occasions permits for proposed plants have been denied because of water availability concerns and potentially adverse effects on aquatic life in various locations internationally [24]. Similarly during droughts there have been occasions that generation plants have been shut down because if operated they would not be compliant with water use regulations [25]. Hence, water use for electricity generation affects regional ecology and security of supply of both water and electricity.

There are different technologies used for cooling which possesses advantages and disadvantages. The most used technologies are: once-through (open-loop) cooling, closed-loop (wet) cooling, dry (air) cooling and hybrid cooling [26].

\subsubsection{Once-Through (Open-Loop) Cooling}

Once-through cooling uses an ample supply of water (from an ocean, river, lake, cooling pond or canal) to run through the system's heat exchanger to condense the low-pressure steam at the exhaust of the turbines. Although these plants do not consume much water (i.e., they return about $99 \%$ of the water to the source), the availability of water is critical to plant operation because of the substantial demand [19]. This makes these plants vulnerable to droughts, high-temperature events and competition for water resources. Moreover, the large intake of water is extremely disruptive for aquatic life, and the discharge temperatures alter aquatic ecosystems considerably. The intake structures may kill fish and other aquatic organisms and the discharge of heated water can be particularly lethal to native aquatic species [27].

\subsubsection{Closed-Loop (Wet) Cooling}

While once-through cooling relies on the high thermal capacity of water, closed-loop cooling relies on the high-energy requirements of water evaporation [19]. Cooling water circulates between the condenser and a cooling tower. These cooling systems have much lower water requirements but consume much more of the withdrawn water. The water source can be from the ocean, a lake, a river, a cooling pond or a canal. Due to stringent regulations concerning open-loop cooling, closed-loop cooling has become the technology used since the 1970s [28]. 


\subsubsection{Dry (Air) Cooling}

Dry cooling systems are very similar to closed-loop systems, but air replaces water to cool the circulating cooling fluid, thus eliminating water withdrawal and consumption. However, this greatly impacts plant efficiency due to a lower thermodynamic theoretical maximum (Carnot cycle) and high electricity use for powering the massive fans used in cooling [19]. Dry cooling is heavily impacted by ambient temperatures and humidity and will perform less well than wet cooling, particularly in hot and dry climates where the use of such technologies is most desirable. The average loss of output is about $2 \%$ annually [29], but can be as high as $25 \%$ at the peak of summer when demand is at its highest [30]. Moreover, the capital cost of such a system is about 10 times more than that of an open-loop system (about \$180/kW [31]), which makes it very unattractive to utilities without massive subsidies and grants. Dry cooling systems are more expensive than conventional wet cooling techniques when considering the infrastructural investments required [32].

\subsubsection{Hybrid Cooling}

Hybrid cooling technology uses a combination of wet and dry cooling systems, where wet and dry cooling components can be used either separately or simultaneously. This way, the system can operate both the wet and dry components together or rely only on dry cooling to avoid water use, economically reducing water requirements of the wet systems by up to $80 \%$. Hybrid cooling uses bundles of cooling elements arranged in concentric rings inside the cooling tower. Heat is conducted from the warm water by these cooling elements, which have cool water flowing through them. Cooling water that flows through the elements is then cooled down by cold air passing over and then returned to the condenser. This system is referred to as a closed system since there is no loss of water due to evaporation. Dry cooling techniques differ in the respect that heat exchange occurs between hot steam leaving the turbine blades and a heat exchanger. Air passing through the exchanger is supplied by multiple electrical fans. The heat forms steam that is removed by the air within the exchanger thereby condensing the steam back into water. Capital costs usually fall midway between wet and dry cooling systems [31].

The adoption of various technologies determines the water consumption in the electricity generation mechanisms in a country.

\subsection{Water consumption in power plant cooling systems}

Water is a critical resource in the operations of all thermoelectric power generation. 'Thermoelectric power generation' is a broad category of power plants consisting of coal, nuclear, oil, natural gas, and the steam portion of gas-fired combined cycles. Thermoelectric generation represents the largest segment of electricity production in a number of countries including South Africa [2].

Water consumption is recognized internationally as an important factor driving decisions on where to build, retrofit or retire cooling stations and even entire power plants ([33]; [30]). However, limited studies investigating water cooling needs exist mainly because of the lack of detailed data. Field data are sparse and of poor quality internationally [26]. Mittal et al. [34] identified significant limitations in the USA data. They state "respondents may use different methods to measure or estimate data, and instructions may be limited or unclear. Respondents may make mistakes or have nontechnical staffs fill out surveys" $(p, 69)$.

Rutberg [23] while discussing the issue states that, "outside the US, available data is generally even sparser. One notable exception, however, is South Africa. Eskom the main public utility maintains detailed accounts of water use at each of their power plants." 
Research on the technical aspects of water use minimization is widespread. For example, the US Department of Energy's (DOE) National Energy Technology Laboratory (NETL) is engaged in a research and development (R\&D) program to reduce freshwater withdrawal and consumption from existing and future thermoelectric power generating facilities. The NETL program can be classified in five categories as described in Error! Reference source not found. .

\section{Table 1: Technology innovations to reduce water usage}

Category Description (Adapted from Feeley et al. [2])

A) Provide alternate source of cooling water make-up
Use of produced water in re-circulated cooling systems at power generation facilities and
development of an impaired water cooling system
Development and demonstration of a modelling framework for Assessing the Efficacy of using mine
water for thermoelectric power generation
Reuse of treated internal or external wastewaters in the cooling systems of coal-based
thermoelectric power plants
B) Increase cycles of concentration for wet re-circulating systems, thereby decreasing wet cooling
tower blow-down requirements
A synergistic combination of advanced separation and chemical scale inhibitor technologies for
efficient use of impaired water as cooling water in coal-based power plants
Application of pulsed electrical fields for advanced cooling in coal-fired power plants
Advanced cooling technology
Use of Air2AirTM technology to recover fresh-water from the normal evaporative cooling loss at
coal-based thermoelectric power plants
Reclaim water from combustion flue gas for use as cooling water make-up
Water extraction from coal-fired power plant flue gas
Recovery of water from boiler flue gas
Reduction of water use in wet FGD system
Reduce cooling tower evaporative losses via coal drying
Use of coal drying to reduce water consumed in pulverized coal power plants

Macknick et al. [35] investigated the water requirements for a number of energy technologies. The technologies addressed consist of configurations of concentrating solar power (CSP), solar photovoltaic (PV), wind, bio-power, geothermal, hydroelectric, nuclear, natural gas and coal technologies. Cooling system technologies considered include wet re-circulating technologies (evaporative cooling towers), oncethrough cooling systems (open loop cooling), air-cooled condensing (dry cooling), hybrid wet and dry cooling systems (hybrid cooling), and pond cooling systems.

Figure 3 shows the operational water consumption factors for different electricity generating technologies. The figure is in the form of box and whisker plots. Whisker ends represent maxima and minima of operation consumption. Upper and lower ends of boxes represent 75th and 25th percentile, respectively. Horizontal lines in boxes represent medians ( $50 \%$ of observations).

Water in the West [19] among others summarised the technologies used for cooling in the USA. Their findings appear in Table 2. 
Table 2: Power plant cooling technologies used in the USA

\begin{tabular}{|c|c|c|c|c|c|c|c|c|c|c|}
\hline \multirow{3}{*}{$\begin{array}{c}\text { Generation } \\
\text { Type }\end{array}$} & \multicolumn{4}{|c|}{ NETL (2009) Based on Platts (2005) } & \multicolumn{6}{|c|}{ EIA Forms 860 \& 923 (2012) } \\
\hline & \multirow{2}{*}{$\begin{array}{c}\text { Wet } \\
\text { Recirc- } \\
\text { ulation }\end{array}$} & \multirow{2}{*}{$\begin{array}{l}\text { Once- } \\
\text { through }\end{array}$} & \multirow{2}{*}{$\begin{array}{l}\text { Cooling } \\
\text { Ponds }\end{array}$} & \multirow{2}{*}{ Dry } & \multirow{2}{*}{$\begin{array}{c}\text { Wet } \\
\text { Recirc- } \\
\text { ulation }\end{array}$} & \multicolumn{2}{|c|}{ Once Through } & \multirow{2}{*}{ Cooling } & \multirow{2}{*}{ Dry } & \multirow{2}{*}{ Hybrid } \\
\hline & & & & & & Freshwater & Seawater & & & \\
\hline \multirow{2}{*}{ Coal } & \multirow{2}{*}{$48.0 \%$} & \multirow{2}{*}{$39.1 \%$} & \multirow{2}{*}{$12.7 \%$} & \multirow{2}{*}{$0.2 \%$} & \multirow{2}{*}{$46.3 \%$} & $33.5 \%$ & $2.8 \%$ & \multirow{2}{*}{$17.0 \%$} & \multirow{2}{*}{$0.4 \%$} & \multirow{2}{*}{$0.0 \%$} \\
\hline & & & & & & \multicolumn{2}{|c|}{$36.3 \%$} & & & \\
\hline \multirow{2}{*}{$\begin{array}{l}\text { Fossil Non- } \\
\text { Coal }\end{array}$} & \multirow{2}{*}{$23.8 \%$} & \multirow{2}{*}{$59.2 \%$} & \multirow{2}{*}{$17.1 \%$} & \multirow{2}{*}{$0.0 \%$} & \multirow{2}{*}{$30.2 \%$} & $28.1 \%$ & $25.5 \%$ & \multirow{2}{*}{$16.2 \%$} & \multirow{2}{*}{$0.0 \%$} & \multirow{2}{*}{$0.0 \%$} \\
\hline & & & & & & \multicolumn{2}{|c|}{$53.6 \%$} & & & \\
\hline \multirow{2}{*}{$\begin{array}{c}\text { Combined } \\
\text { Cycle }\end{array}$} & \multirow{2}{*}{$30.8 \%$} & \multirow{2}{*}{$8.6 \%$} & \multirow{2}{*}{$1.7 \%$} & \multirow{2}{*}{$59.0 \%$} & \multirow{2}{*}{$71.3 \%$} & $7.4 \%$ & $6.1 \%$ & $29 \%$ & $117 \%$ & $06 \%$ \\
\hline & & & & & & 13. & & 2.570 & $11.7 / 0$ & $0.0 \%$ \\
\hline Nurloar & $126 \%$ & $201 \%$ & $182 \%$ & ( & $360 \%$ & $31.1 \%$ & $20.2 \%$ & $127 \%$ & \% & ( $0 \%$ \\
\hline ivuctedr & $43.0 \%$ & $30.1 \%$ & $18.3 \%$ & $0.0 \%$ & $50.0 \%$ & 51. & & $12.1 \%$ & $0.0 \%$ & $0.0 \%$ \\
\hline Total & $41.9 \%$ & $42.7 \%$ & $14.5 \%$ & $0.9 \%$ & $49.1 \%$ & $26.7 \%$ & $8.5 \%$ & $12.7 \%$ & $2.9 \%$ & $0.1 \%$ \\
\hline
\end{tabular}

Source: Adapted from Water in the West [19].

The authors further concluded that their analysis shows that water intensities exhibit strong variability within fuel types and cooling types. Yang and Driegielewski [36] investigated the major determinants of water withdrawal and consumption in terms of types, cooling system types; operation conditions; and water sources. NETL [37] used detailed process models of state of the art fossil fuel power plants to benchmark water use plant performance.

Chandel et al. [38] investigated how climate change policy involving a price on carbon would change the mix of power plants and the amount of water they withdraw and consume to generate electricity. The authors find that under all the climate-policy scenarios, fresh water withdrawals decline between $2 \%$ and $14 \%$ relative to a business-as-usual scenario of no U.S. climate policy. Furthermore, water used decreases as the price on $\mathrm{CO} 2$ under the climate policies increases. At relatively high carbon prices (> $\$ 50 /$ tonne $\mathrm{CO} 2$ ), however, retrofitting coal plants to capture $\mathrm{CO}_{2}$ increases freshwater consumption compared to business as usual in 2030. The analysis suggests that climate policies and a carbon price will reduce both electricity generation and freshwater withdrawals compared to business as usual unless a substantial number of coal plants are retrofitted to capture $\mathrm{CO}_{2}$.

Zemlick et al. [39] explored the suitability of using non-traditional sources of water, namely wastewater and brackish ground water for future thermoelectric cooling in 22 continental Electricity Market Module Regions and linked them to electricity demand to 2013. They argued that while neither resource can meet all future demand by thermoelectric generation, when added to the existing water supply and management portfolio, they provide significant augmentation to existing traditional water supplies.

A number of studies investigated the effects of climate change on the European power sector ([40]; [41]). Hydropower and thermoelectric (nuclear and fossil-fuelled) power plants currently contribute more than 91\% of total electricity production in Europe. The investigations show that the combination of increased water temperatures and reduced summer river flow under climate change is likely to affect both hydropower and thermoelectric power generating capacity in Europe, with distinct impacts on electricity prices. 


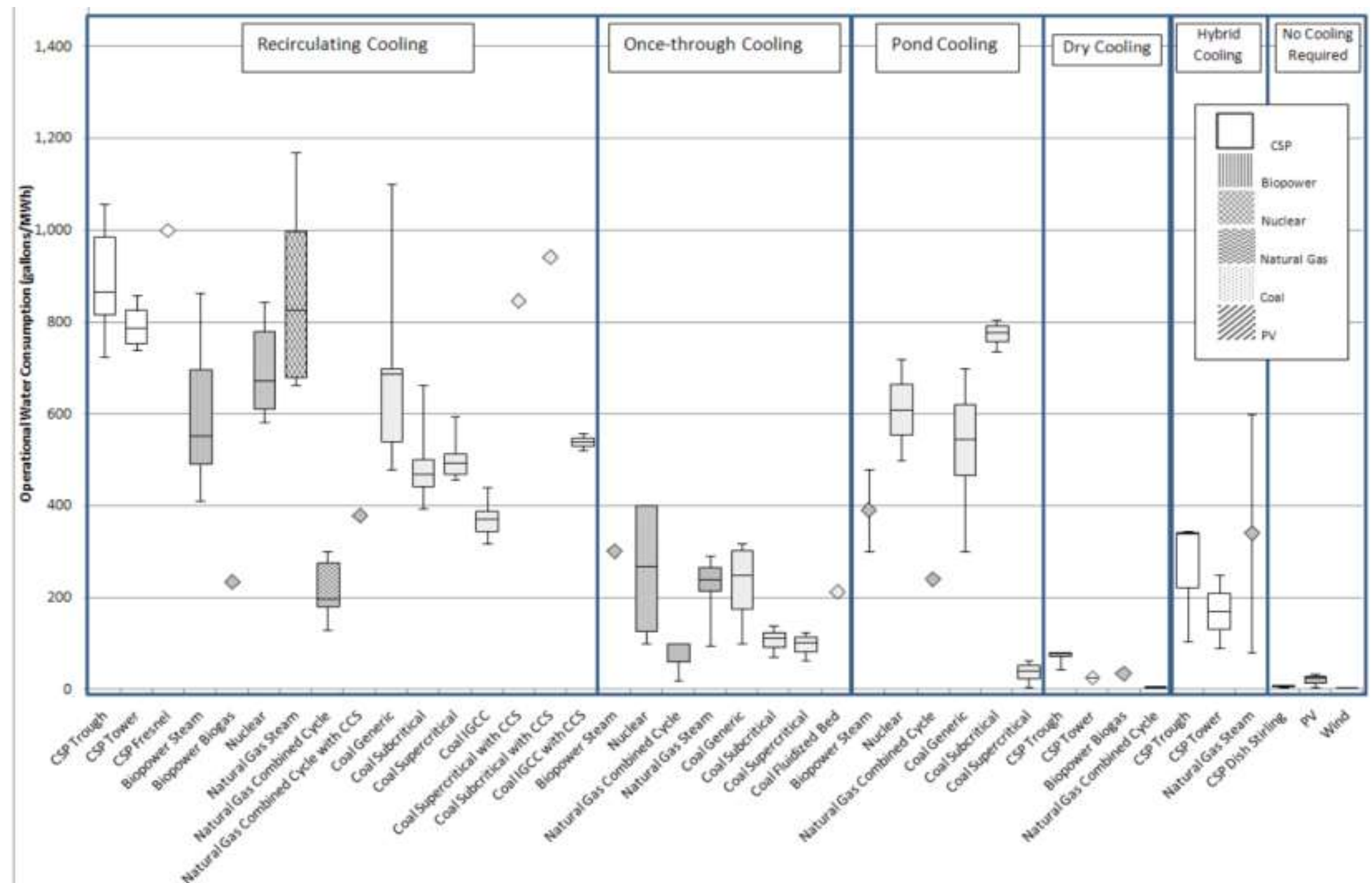

Figure 3: Operational water consumption factors for electricity generating technologies [35]

IGCC: Integrated gasification combined cycle; CCS:Carbon capture and sequestration; CSP: Concentrating solar power; 1 US gallon = 3.785 litres. 


\subsection{Water demand forecasting}

There are a limited number of investigations in the open literature forecasting water demand for electricity generation. As already discussed lack of detailed data contributes to that scarcity. Examples of relevant investigations include the following:

Feeley et al. [2] developed 25 year forecasts of thermoelectric water use in the USA. The authors used a set of model plant profiles essential categories broken out by plant and cooling system configuration. For each profile, associated water withdrawal and consumption factors were calculated with EIA survey data. Water use was projected using different scenarios specifying electricity demand, generation mix (model plants) and penetration of water use reduction technologies.

King et al. [42] projected power plant water use in the state of Texas over a 10 year time frame. The study focused on individual plants and when data were not available default withdrawal and consumption factors were used.

The National Energy Technology Laboratory [43] estimated future freshwater withdrawal and consumption from domestic thermoelectric generation sources for five cases, using regional projections for capacity additions and retirements. The results suggest that carbon capture technologies could increase the water demand of thermoelectric power plants and indicate that consumption is expected to increase in all cases.

NETL [44] updated the previous reports. The broad methodology is as follows:

Step 0: Estimate future capacity and generation: Annual Energy Outlook 2013 projections of capacity and generation to 2035 are used in the analysis to calculate future thermoelectric generation water withdrawal and consumption.

Step 1: Develop model plants: The existing thermoelectric fleet was segregated into numerous configurations, called "model plants".

Step 2: Calculate water withdrawal and consumption factors: For each model plant defined in Step 1, water withdrawal and consumption factors were calculated

Step 3: Quality Control and Model Validation Step 3 represents efforts designed to ensure quality control for the analysis. The water withdrawal and consumption factors that were used in the model were obtained through a rigorous statistical evaluation. Box-plots of data were used to identify outliers.

Step 4: Develop Future Cases Future water withdrawal and consumption for the U.S. thermoelectric generation sector are estimated for five cases - one reflecting status quo conditions, two reflecting varying levels of regulations regarding cooling water source, one incorporating dry cooling and one reflecting regulatory pressures to convert existing once-through capacity to re-circulating capacity.

\section{Step 5: Calculate regional withdrawal and consumption to 2035}

Step 5 integrates the water withdrawal and consumption factors calculated in Step 2 with the various cases defined in Step 4 to assess the regional and national impacts on water withdrawal and consumption out to 2035.

A few studies have attempted to analyse water usage patterns in different sectors in South Africa (e.g. [45], [46]). 
However, the forecasting of water usage in power generation is an aspect that requires further attention and is analysed further in this report. At this juncture the introduction of the South African coal based electricity generation is warranted before delving into water forecasting.

\subsection{Coal based electricity production in South Africa}

South Africa has 13 coal power plants of which ten are base load power plants while three are return to service power plants used for peak demand times [47]. Base load power stations are those that operate to deliver base (or normal) demand. Peak load power stations are operated or switched on in conjunction with base load plants to supply power during periods of peak demand. The current fleet of coal power plants use a combination of technologies for cooling. Figure 4 and Table 3 provides a summary of the location of the coal power plants in South Africa and the cooling technologies used in each power plant respectively.

Table 3 shows the cooling technologies being used in Eskom's current and future coal-fired plants; their geographic location and the year of their completion. As discussed, the wet recirculation cooling technology, uses cooling water through condenser tubes with steam on the outside. The temperature variation between the water and steam causes condensation. The warm water in the condenser is collected in the cooling tower where an upward draft of air removes the heat. The cooled water is then recirculated to the condenser. A major drawback of this technique is that water is lost through evaporation when the warm cooling water comes in contact directly with air [48].

Table 3: Cooling technologies in Eskom coal power stations (current and future)

\begin{tabular}{|l|l|l|l|l|}
\hline Category & Name & Cooling technique & Location & Year of completion \\
\hline \multirow{5}{*}{ Base load } & Arnot & Wet recirculating & Mpumalanga & 1975 \\
\cline { 2 - 5 } & Duvha & Wet recirculating & Mpumalanga & 1984 \\
\cline { 2 - 5 } & Hendrina & Wet recirculating & Mpumalanga & 1970 \\
\cline { 2 - 5 } & Kendal & Indirect dry & Mpumalanga & 1993 \\
\cline { 2 - 5 } & Kriel & Wet recirculating & Mpumalanga & 1979 \\
\cline { 2 - 5 } & Lethabo & Wet recirculating & Limpopo & 1991 \\
\cline { 2 - 5 } & Majuba & Wet recirculating and dry & Mpumalanga & 2000 \\
\cline { 2 - 5 } & Matimba & Direct dry & Mpumalanga & 1991 \\
\cline { 2 - 5 } service & Matla & Wet recirculating & Mpumalanga & 1983 \\
\cline { 2 - 5 } & Tutuka & Wet recirculating & Mpumalanga & 1990 \\
\hline \multirow{2}{*}{ New build } & Camden & Wet recirculating & Mpumalanga & 1967 \\
\cline { 2 - 5 } & Grootvlei & Wet recirculating and dry & Mpumalanga & 1973 \\
\cline { 2 - 5 } & Komati & Wet recirculating & Mpumalanga & 1966 \\
\cline { 2 - 5 } & Medupi & Direct dry & Limpopo & On-going \\
\cline { 2 - 4 } & Kusile & Direct dry & Mpumalanga & On-going \\
\hline
\end{tabular}



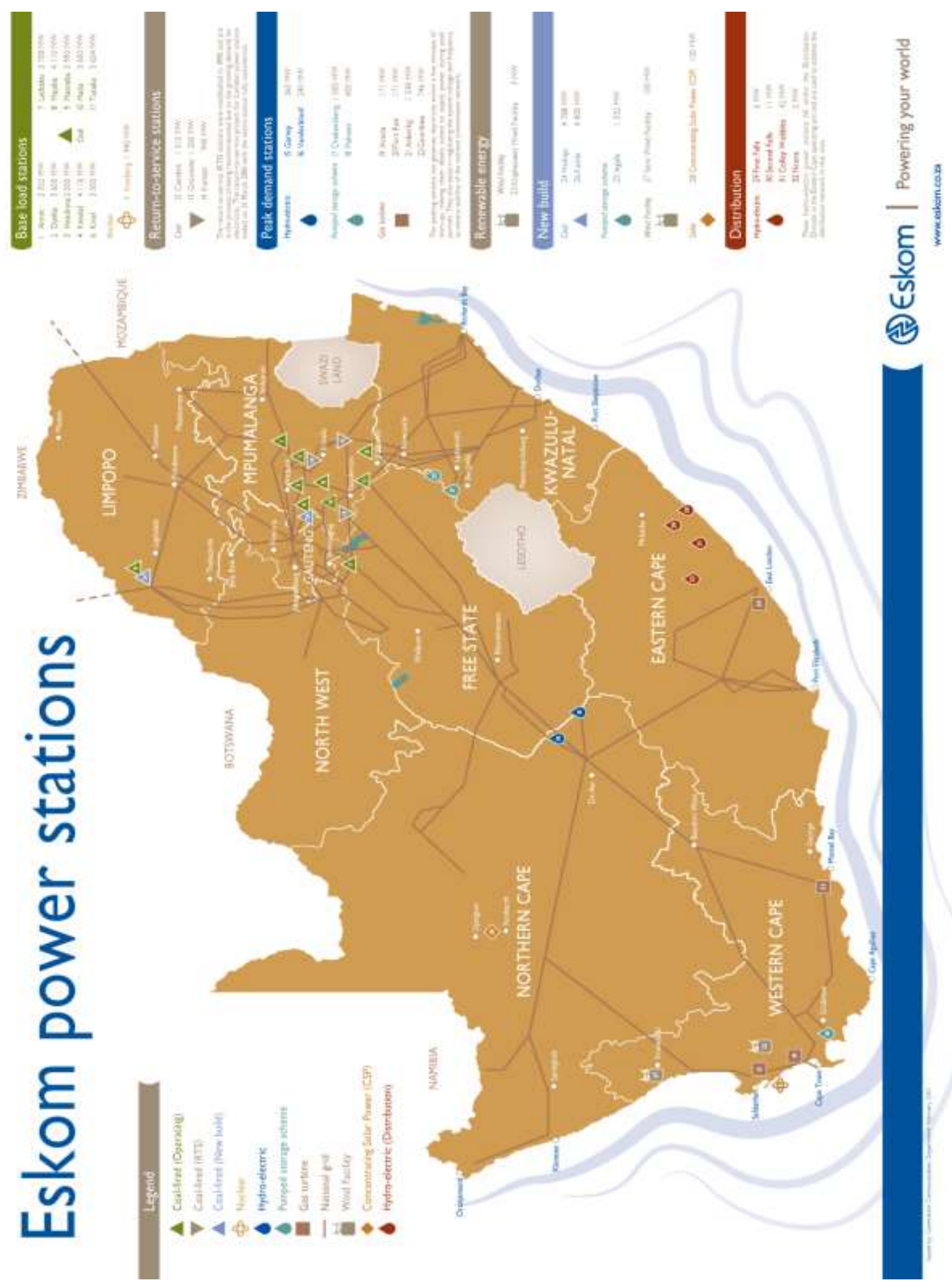

Figure 4: Eskom power plants 
Of the 10 existing base load coal power plants, eight use wet recirculation cooling technologies while two (Kendal and Majuba) use dry cooling approaches. The dry cooling technology uses air instead of water in the heat exchange mechanism to cool down high temperature steam.

In summary, the need for water use forecasting in the topic of energy-water nexus, is essential in South Africa. The literature review identifies that European researchers place particular emphasis on the effects of environmental changes on the demand for water. Furthermore the review shows that total water usage and water usage consumption factors are primarily dependent on the type of cooling technology used. However other factors such as physical location of power plant, efficiency of power plant, type of boiler used, type of coal used, etc., are also important factors when estimating water usage patterns. Therefore accurate accounting of water consumption has to be attributed based on the priority of the factors listed above. The more important quantifiable technical factors for South African coal power plants are discussed in the following section along with the assumptions used within the methodology.

\section{Methodology}

In this section the baseline assumptions and methodology are presented. The first section provides the criteria on which the baseline assumptions have been derived, while the second section explains the methodology and the mathematical model.

\subsection{Assumptions}

The assumptions used within this study are based on the foundations of the revised Integrated Resources Plan (IRP) baseline case step 5 (BCS5) [50]. The revised IRP takes into account the ministerial determinations made post 2010, by taking into consideration the allocation of renewable programmes in 2011 and 2012. However, the current study has taken the liberty of making certain realistic assumptions based on the current state of the South African economy and the electricity industry.

The assumptions are structured to provide four sets of information on varied, but related topics, namely;

- Assumption differentiation between current study and BCS5 scenario.

- Electricity capacity demand analysis

- Technical assumptions

- Scenario analysis

The assumptions are listed in tabular form (Table 4) and are contrasted with the revised IRP BCS5 assumptions.

Table 4: Assumption differentiation between current study and BCS5 scenario

\begin{tabular}{|l|l|l|}
\hline Criteria & Current study & BCS5 scenario \\
\hline Return to & The water forecasting study assumes that the & The BCS5 scenario decommissioning \\
Service (RTS) & $\begin{array}{l}\text { RTS fleet will be decommissioned by the year } \\
\text { 2020. This assumption is in order to prevent } \\
\text { increasing water usage per unit of electricity } \\
\text { generated. }\end{array}$ & $\begin{array}{l}\text { the RTS fleet will be operational until } \\
\text { the year 2030. The phase out is } \\
\text { scheduled over a 10 year period } \\
\text { starting from 2020. }\end{array}$ \\
\hline
\end{tabular}




\begin{tabular}{|l|l|l|}
\hline Criteria & Current study & BCS5 scenario \\
\hline Existing fleet & $\begin{array}{l}\text { The current study assumes that the life of older } \\
\text { power plants such as Hendrina, Arnot and Kriel } \\
\text { will be extended to operate fully or partially as } \\
\text { an alternative to the RTS fleet which has poorer } \\
\text { water efficiency factors. }\end{array}$ & $\begin{array}{l}\text { The BCS5 scenario assumes power } \\
\text { plants Hendrina, Arnot and Kriel (total } \\
\text { of 7200 MW) to be fully } \\
\text { decommissioned before the year 2030. }\end{array}$ \\
\hline New build & $\begin{array}{l}\text { The new build power stations of Medupi and } \\
\text { Kusile are expected to come online the national } \\
\text { grid between the years on 2015 \& 2020. This is } \\
\text { in conjunction with the decommissioning of the } \\
\text { RTS fleet. }\end{array}$ & $\begin{array}{l}\text { Medupi and Kusile are categorised as } \\
\text { part of the existing fleet. The timelines } \\
\text { set for the first units of these power } \\
\text { plants are 2014 and 2015 respectively. }\end{array}$ \\
\hline New coal & $\begin{array}{l}\text { The current study acknowledges the presence } \\
\text { of new coal technologies in the future of the } \\
\text { coal road map in South Africa but refrains from } \\
\text { technolimating water usage patterns in these } \\
\text { technologies because of the ambiguity } \\
\text { associated with these technologies on a } \\
\text { commercial scale locally. }\end{array}$ & $\begin{array}{l}\text { The BCS5 scenario allocates 2450 MW } \\
\text { of capacity associated with new coal } \\
\text { technologies such as underground coal } \\
\text { gasification (UCG), advanced pulverised } \\
\text { fuel (PF) and fluidised bed combustion } \\
\text { (FBC) technologies. }\end{array}$ \\
\hline Total capacity & $\begin{array}{l}36900 \text { MW } \\
\text { 36230 MW }\end{array}$ \\
\hline
\end{tabular}

\section{Electricity capacity demand analysis}

Electricity supply and demand are in a critical stage in South Africa. At this point in time the installed capacity, taking into account the base load power plants (35000 MW) and RTS fleet (3000MW) is a total of approximately $38000 \mathrm{MW}$ while the nominal capacity is estimated to be $35700 \mathrm{MW}[47]^{1}$. Based on the IRP BCS5 the estimated installed capacity for existing coal technologies ${ }^{2}$ (which includes Medupi and Kusile at $9600 \mathrm{MW}$ ) for the year 2030 is $36900 \mathrm{MW}$ (IRP 2010, p20 and p75). Therefore installed capacity in 2030 for currently operating base load plants would be $27300 \mathrm{MW}$ which is after the decommissioning of the RTS fleet [50].

At current levels of generation (213 TWh), existing power plants are operating at a capacity factor of $77.8 \%$ which is typically high and unsustainable for current fleet of older power plants. The presence of the new build power plants (Medupi and Kusile) with a capacity of $9600 \mathrm{MW}$ is bound to reduce the load on the existing fleet. The decommissioning of the RTS fleet would bring total available coal power installed capacity to $36900 \mathrm{MW}$ (with existing base load contributing $27300 \mathrm{MW}$ and new build at $9600 \mathrm{MW}$ ).

However it is critical to note that even if the new build power plants are operated at a capacity factor of $80 \%$ which is realistic for the type of technology, the strain on the existing base load plants and the national grid will not ease unless other newer power plants (nuclear, renewable, gas, etc) are available.

The current study projects that based on current demand trends, taking into account availability of the new build power plants and decommission of the RTS fleet in combination with the current base load power

\footnotetext{
${ }^{1}$ These figures do not take into account the decrease in nominal capacity due to unplanned maintenance which has led to the 2014-2015 load shedding scenario.

${ }^{2}$ Existing coal technologies according to the IRP include current base load power plants and Medupi and Kusile. These power plants are categorised separate from new coal technologies.
} 
plants, total demand could reach $255 \mathrm{MWh}$ by the year 2030, which can be supplied at $78.4 \%$ capacity factor. These assumptions are in line with Eskom's capacity factor assumptions of 80:10:10 for the coal power plant fleet, which means that $80 \%$ of the total capacity is available any time, while $10 \%$ is scheduled for planned outages and the remaining $10 \%$ scheduled for unplanned outages.

\section{Technical factors:}

The current study takes into account primary power plant operational parameters in the forecasting model, which are;

- Deduced capacity factor

- Boiler technology

- Cooling type technology

- Thermal efficiency

The aforementioned factors are the major technical determinants that affect the performance of a coal power plant and thereby directly and indirectly altering the water usage and consumption trends.

\section{Scenario analysis:}

The generation study provides analysis based on multiple scenarios categorised on technology type and load type; those being:

- Base load

wet cooled base load

dry cooled base load

- RTS analysis

- New build analysis

- Combined cases

The analyses of these scenarios are necessary and relevant when taking into account the current fleet of South African coal power plants. The scenario analysis also takes into account projections for new build power plants Medupi and Kusile, which are expected to be part of the national grid within the next two years.

\subsection{Mathematical model}

The pathway used to estimate (or forecast) the water usage consumption is based on the development of a model which forms a combination of steps uniquely developed for this study and from those mentioned within the NETL methodology (in section 2.3). Since long term generation output forecasts or water usage factors are not available for individual South African coal-fired power plants, a mathematical forecasting model had to be developed to estimate generation output. The forecasting model relies on historical water consumption and electricity generation data, for each of Eskom's power plants, from the year 1989 to 2012, obtained from Eskom's data archives. The forecasting technique is based on a moving average forecast in order to accommodate average yearly values of water usage and generation output estimates [51]. The considered forecasting technique helps in minimising the effects of anomalies within data sets, provided long term data sets are available, which is the case in this instance.

The method uses the estimation steps used in the NETL methodology [44]. However the forecasting technique used during the estimation steps varies from the NETL methodology. The primary steps involved in the devised methodology are as follows: 
1) Estimate future long-term generation output of each coal fired power plant

2) Estimate future water consumption factor for each power plant based on future generation output and average system thermal efficiency

3) Estimate total water usage from steps 1 and 2

4) Scenario building based on technology and time-period

\section{Step 1}

The estimation of long-term generation output is based on historical generation patterns obtained from the electricity utility Eskom's, data archives. ${ }^{1}$ Since generation output can be highly irregular from year to year, a mathematical model had to be developed which took into account historical data patterns. A variant of the basic extrapolation formula had to be developed to take into historical data averages.

The basic linear extrapolation formula can be indicated as:

$\left.(G C)_{n+1}=(G C)_{n-1}+\left[\frac{[(n+1)-(n-1)]}{[n-(n-1)]}\right] *\left[(G C)_{n}-(G C)_{n-1}\right)\right]$

where

$\mathrm{GC}=$ generation output in kilowatt hour $(\mathrm{kWh})$

$\mathrm{n}=$ year of analysis

However, the basic extrapolation formula cannot be used to estimate a long-term generation forecast because the basic formula does not take into account long term generation trends. A ten year moving average is derived as shown in equation 2 to take into account historical generation patterns. This logic can be validated because most of Eskom's coal fired base load power stations have been running on consistently high capacities due to high demands. ${ }^{2}$

$(G C)_{n+1}=(G C)_{n 10 \text { avg }}^{i=n-1 \text { to } n-10}+\left[\frac{\left[(n+1)-n_{10 \text { avg }}^{i=n \text { to } n-9}\right]}{\left[(n)-n_{10 \text { avg }}^{i=n-1 \text { to } n-10)}\right]}\right] *\left[(G C)_{n 10 \text { avg }}^{i=n \text { to } n-9}-(G C)_{n 10 \text { avg }}^{i=n-1 \text { to } n-10}\right]$

where,

$(G C)_{n+1}=$ generation output in kilowatt hour in year $(\mathrm{n}+1)(\mathrm{kWh})$

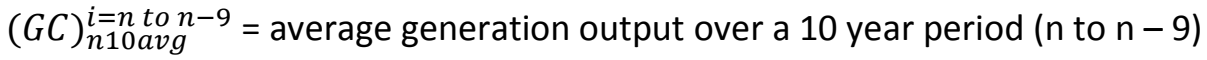

$(G C)_{n 10 \text { avg }}^{i=n-10}=$ average generation output over a 10 year period $(n-1$ to $n-10)$

$n_{10 a v g}^{i=n-1}$ to $n-10=10$ year time sum average from year $(n-1)$ to $(n-10)$

The generation output for year $(n+1)$ is determined by multiplying the 10 year time average with the difference in the average generation output over a 10 year period. This term is then summed with average

\footnotetext{
${ }^{1}$ In this study demand forecasting was not considered because of the variable (or external) conditions affecting electricity demand, such as economic growth, commodity prices, union strikes, maintenance outages, etc. The methodology used in this study does not model external shocks.

${ }^{2}$ Though electricity demand is usually linked to GDP growth, the current electricity crisis has caused a negative impact on growth because of the lack of available electricity supply. Therefore linking electricity demand to economic growth in the current situation could generate a distorted impression.
} 
generation output from over a 10 year period two years prior to $(n+1)$. For example, the generation output for year 2017 is determined by, first multiplying the difference of the average generation output between the periods 2016 to 2007 and 2015 to 2006 with the time sum average coefficient. This term is then summed with the average generation output from the period 2015 to 2006.

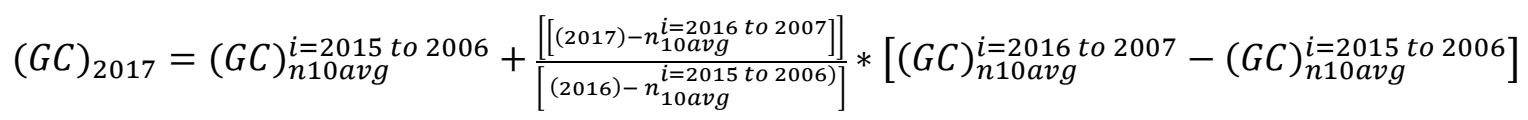

\section{Step 2}

The next step involves estimating the long term consumption factor of the power plants by also including the influence of change in generation output and system thermal efficiency. The formula derived to estimate the consumption factor can be generalised as an exponential weighted moving average (EWMA) formula which can be expressed as,

$$
(C F)_{n+1}=(C F)_{n}\left[\frac{1}{(1+\% \alpha)}\right]+(C F)_{n}\left[\frac{(G C)_{n+1}-(G C)_{n 10 a v g}^{i=n \text { to } n-9}}{(G C)_{n 10 a v g}^{i=n t o n-9}}\right]
$$

where,

$(\mathrm{CF})_{\mathrm{n}+1}=$ Consumption factor in litres per kilowatt hour in year $(\mathrm{n}+1)(\mathrm{l} / \mathrm{kWh})$

$(\mathrm{CF})_{\mathrm{n}}=$ Consumption factor in litres per kilowatt hour in year $(\mathrm{n})(\mathrm{l} / \mathrm{kWh})$

$\% \alpha=$ percentage change in $\alpha$, where $\alpha$ is system thermal efficiency

The $\alpha$ values used for base load power plants are derived from Eskom's annual reports over the past 10 years. Sub-critical power plants which form the core of the coal power plant fleet have a design value of $38 \%$ whereas super-critical power plants (which include Medupi and Kusile) have a design value of $42 \%$ [52].

\section{Step 3}

Based on the calculations made in steps 1 and 2, the water consumption for each power plant can be determined by multiplying the results of equation (2) and (3). Therefore water consumption can be denoted as:

$(W C)_{n+1}=(G C)_{n+1} *(C F)_{n+1}$

\section{Step 4}

Multiple scenarios are developed based on technology type and time of introduction of new technologies. Examples of multiple scenarios include consideration of Return to Service (RTS) power plants. The RTS power plants included are Camden, Grootvlei and Komati. These power plants are considered to have system thermal efficiencies smaller than the existing base load power plants. The reduced system thermal efficiency for RTS fleet is taken into consideration when calculating the water consumption factors.

The RTS fleet is modelled based on the assumption that it will be retired by the year 2020 when the new build power stations of Medupi and Kusile will be fully operational (also taking into account possible delays). However, the first units of Medupi and Kusile are modelled to be operational in the year 2015 and 2016 respectively. The water consumption factor profile of Medupi and Kusile is estimated by following the water consumption factor profile of Matimba power station which also uses dry cooling technology. However, an improved system thermal efficiency factor is considered for the new build power plants because of the supercritical technology that will be used which will add to improved efficiencies. 
The scenarios are developed for three separate categories based on generation profile, namely

- base load

- return to Service (RTS)

- new build

Another form of classification is based on the type of cooling technology used within the current base load and RTS fleet as well as the new build power plants, which can be differentiated as,

- wet cooling

- dry cooling

\section{Results}

Steps 1 to 3 in the previous section are computed and analysed based on the multiple scenarios listed in step 4 of the previous section. The results of the analysis are presented in this section based on generation profile and cooling technology. It should be noted that all data points within the results till the year 2012 is from data provided by Eskom [53] which has been used to make projections.

\subsection{Base load analysis}

The base load water consumption factor profile, which includes the power stations Arnot, Hendrina, Duvha, Kriel, Kendal, Tutuka, Matla, Lethabo, Matimba and Majuba (also mentioned in Table 3), is presented first in Figure 5.

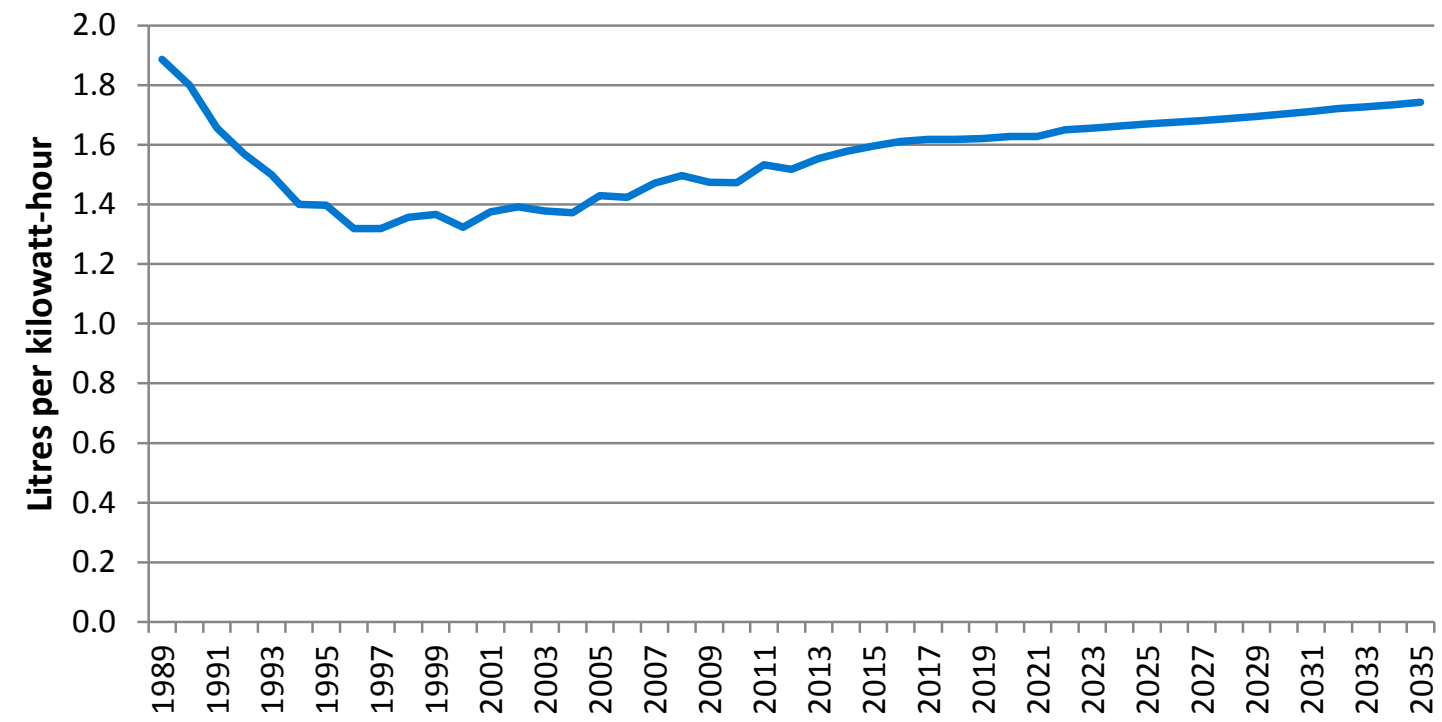

Figure 5: Base load power plant water consumption factor projection

The figure above shows a profile which has seen a sharp decline in the early nineties. This is attributed to the addition of the dry cooling power plants, Kendal and Matimba which has helped in lowering the overall base load consumption factor. However, since the mid-nineties there has been a steady increase with the increase being sharper within the last five years. The recent increase is attributed to the addition of the RTS power plants which are older and less efficient than the base load fleet. The profile from the year 2014 onwards is a projection based on decreasing system thermal efficiencies and historical consumption factors. The consumption factor profile is derived from projected generation output which is shown in Figure 6. 


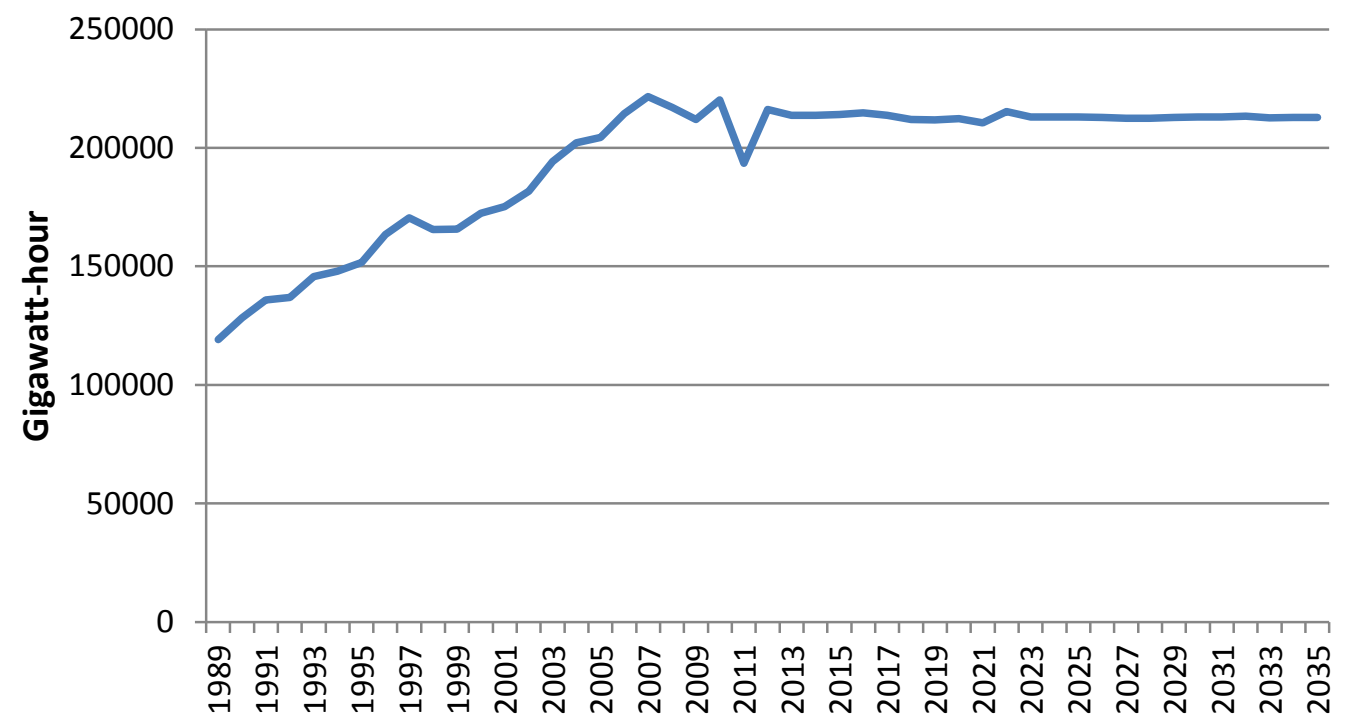

Figure 6: Base load power plant generation output projection

It can be seen that the base load generation output remains steady in line with roughly 213 Terawatt.hour (TWh) which is in line with the scenario that South Africa's base load capacity is being operated at maximal levels. This situation is primarily the reason why new-build power plants are being built. Combining the projections of base load capacity and water consumption factors the total water consumption is projected as shown in Figure 7.

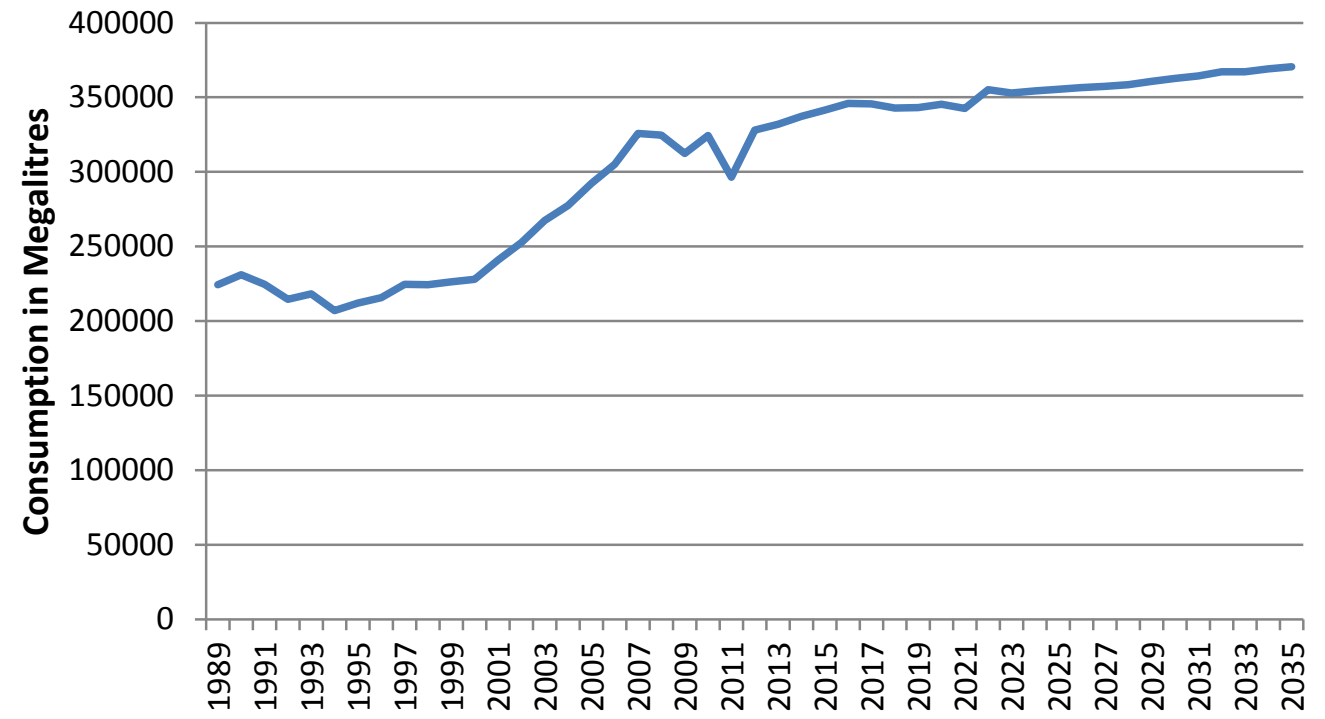

Figure 7: Base load total power plant total water consumption projection

Based on the projection in Figure 7 the total base load water consumption will increase from 332 gigalitres (in 2013) to roughly 370.5 gigalitres (in 2035) which is marginally more than a $10 \%$ escalation (over the 
period). The steady increase in water consumption can be attributed mostly to the deteriorating $\alpha$ value and the marginally increasing generation output. ${ }^{1}$

\subsubsection{Wet cooled base load analysis}

Wet cooled base load plants include all base load plants other than Kendal and Matimba. Majuba which uses a combination of both wet and dry cooling techniques is categorised as a wet cooling plant since it generates the majority of the electricity through wet cooling techniques. Figure 8 shows the consumption factor profile for the wet cooled base load power plants.

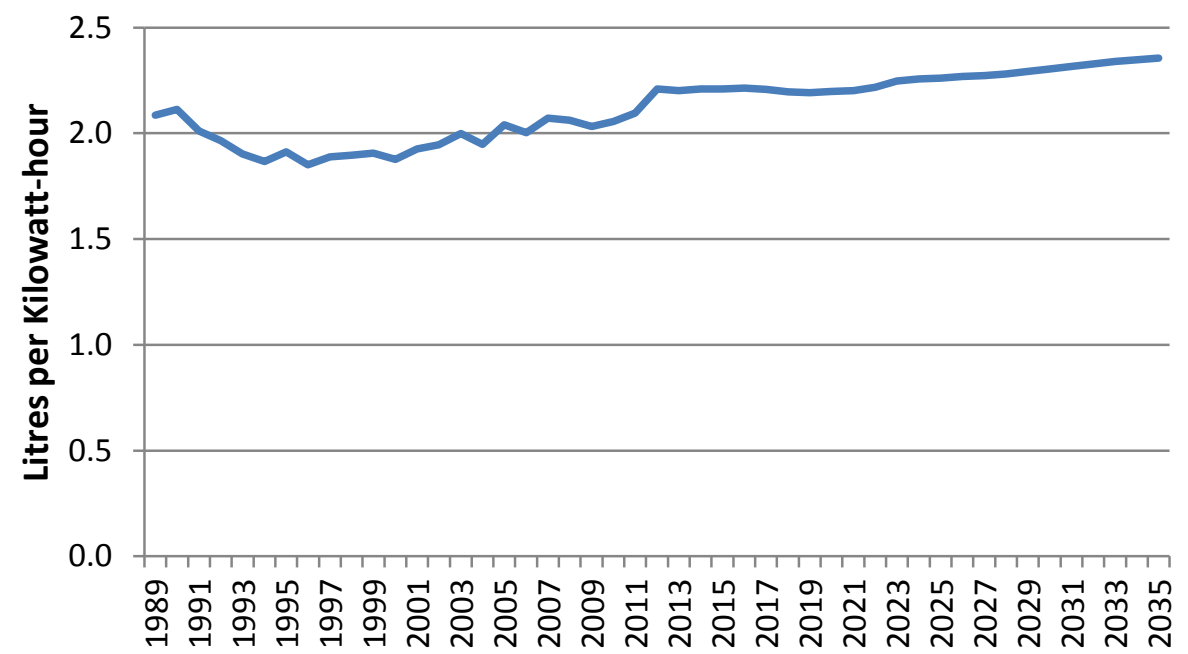

Figure 8: Wet cooled base load water consumption factor projection

Figure 9 shows the total water consumption from wet cooled base load power plants. It can be noticed from the graph that total water consumption of individual power plants have been increasing at a very gradual pace.

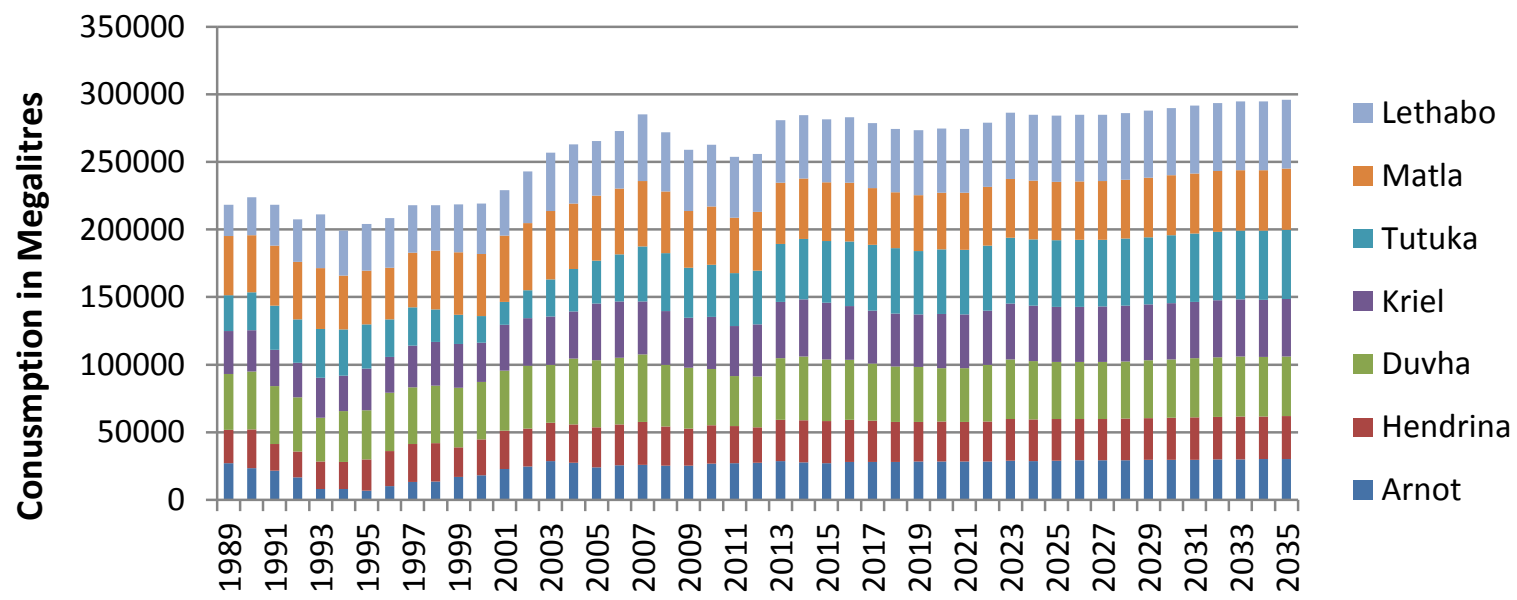

Figure 9: Wet cooled power plant total water consumption projection

\footnotetext{
${ }^{1}$ See step 2 of section 3.2 for a description on $\alpha$ value
} 


\subsubsection{Dry cooled base load analysis}

The dry cooled power stations include Kendal and Matimba which are newer amongst the base load power station fleet. Figure 10 illustrates the consumption factor profile for the dry cooled base load power plants.

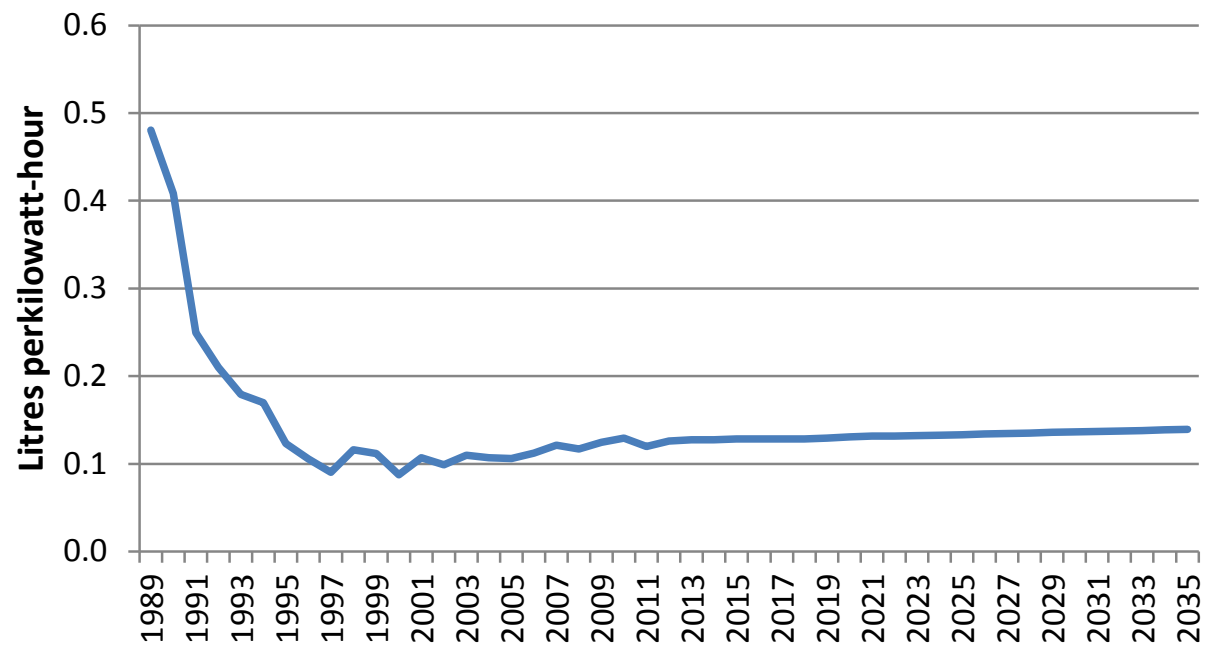

Figure 10: Dry cooled base load water consumption factor projection

These consumption factors are one order of a magnitude lower than the water consumption factors of wet cooled power plants. Figure 11 indicates the total water consumption from dry cooled base load power plants.

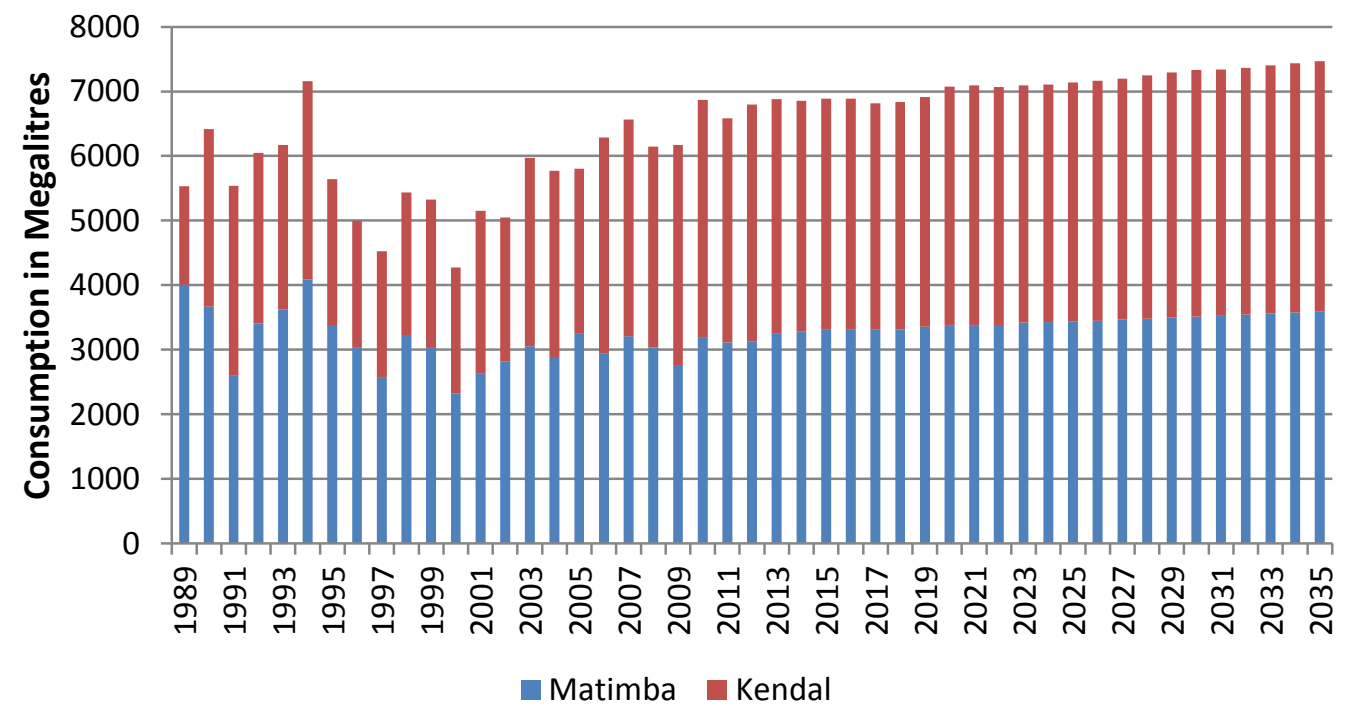

Figure 11: Dry cooled power plant total water consumption projection

Comparisons between Figure 9 and Figure 11 show the difference in total water consumption of power plants using wet and dry cooling technologies. 


\subsection{Return to Service analysis}

The RTS fleet includes the power stations of Camden, Grootvlei and Komati which were re-commissioned between the years of 2006 and 2009 to aid the stretched base load capacity. It is assumed that these power stations will be put out of service once the new build power stations are fully operational. As a conservative choice these power stations are assumed to be operational until the year 2020. Figure 12 depicts the water consumption factor for the RTS fleet.

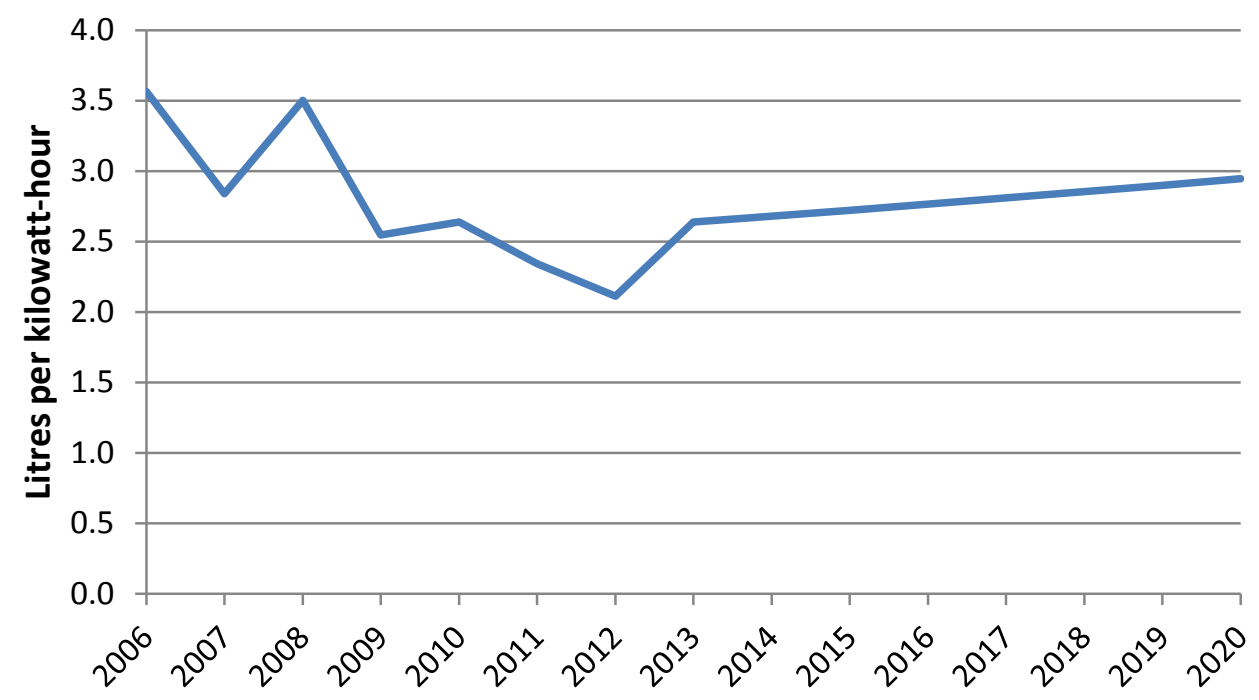

Figure 12: RTS power plant water consumption factor projection

It can be observed that the water consumption factor of the RTS fleet is bound to rise at a higher rate than the base load fleet primarily because of the lower system thermal efficiencies. The same increases can be attributed to total water consumption of the RTS fleet as shown in Figure 13.

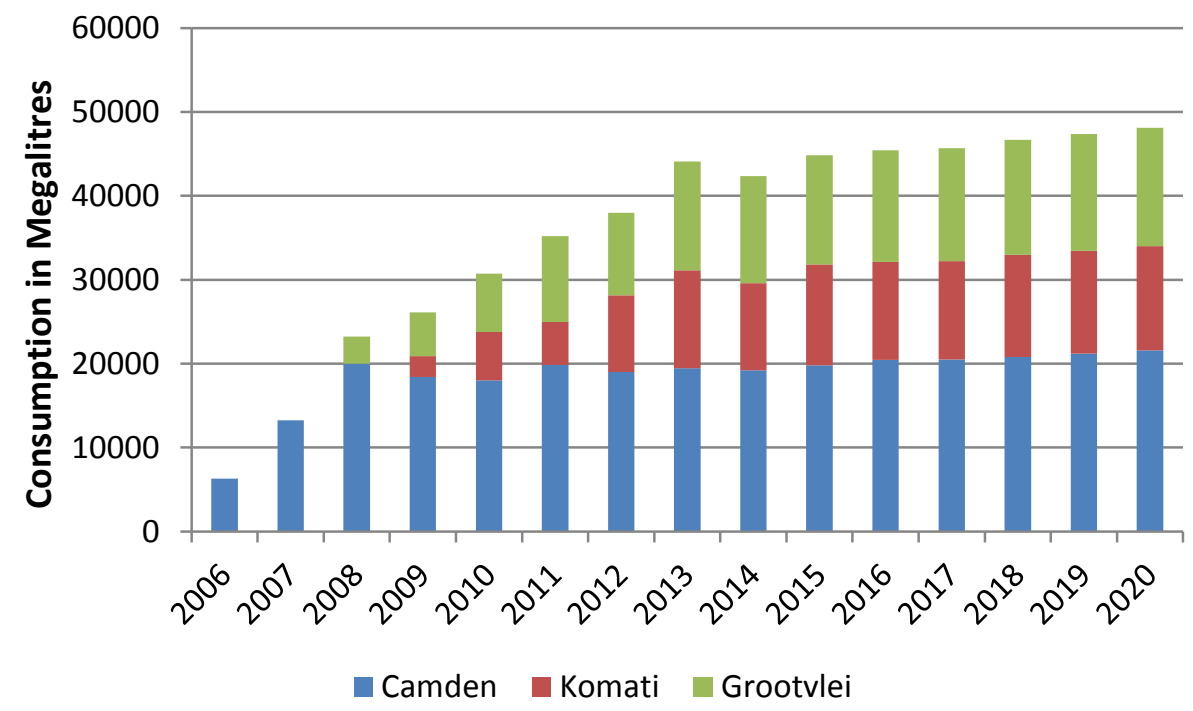

Figure 13: RTS total power plant total water consumption projection 
The inference therefore is that though the RTS fleet provides vital added supply during periods of peak electricity demand, the rate of water consumption associated is higher. Therefore, it is vital (from a water perspective) to retire the RTS fleet as soon as the new-build power plants can be commissioned.

\subsection{New build analysis}

The new build power plants of Medupi and Kusile use dry cooling technologies combined with supercritical boilers which result in better power plant performance and efficiency. Since no prior data is available for either power plant the water consumption factor profile of Matimba which also uses dry cooling technology was used as a baseline. Both Kusile and Medupi were assumed to provide an average system thermal efficiency of $42 \%$, which is the average international rating for dry cooled, supercritical coal power plants, as opposed to an average $32 \%$ for the current base load subcritical power plants. Figure 14 provides the average water consumption factor projection for both new build power plants.

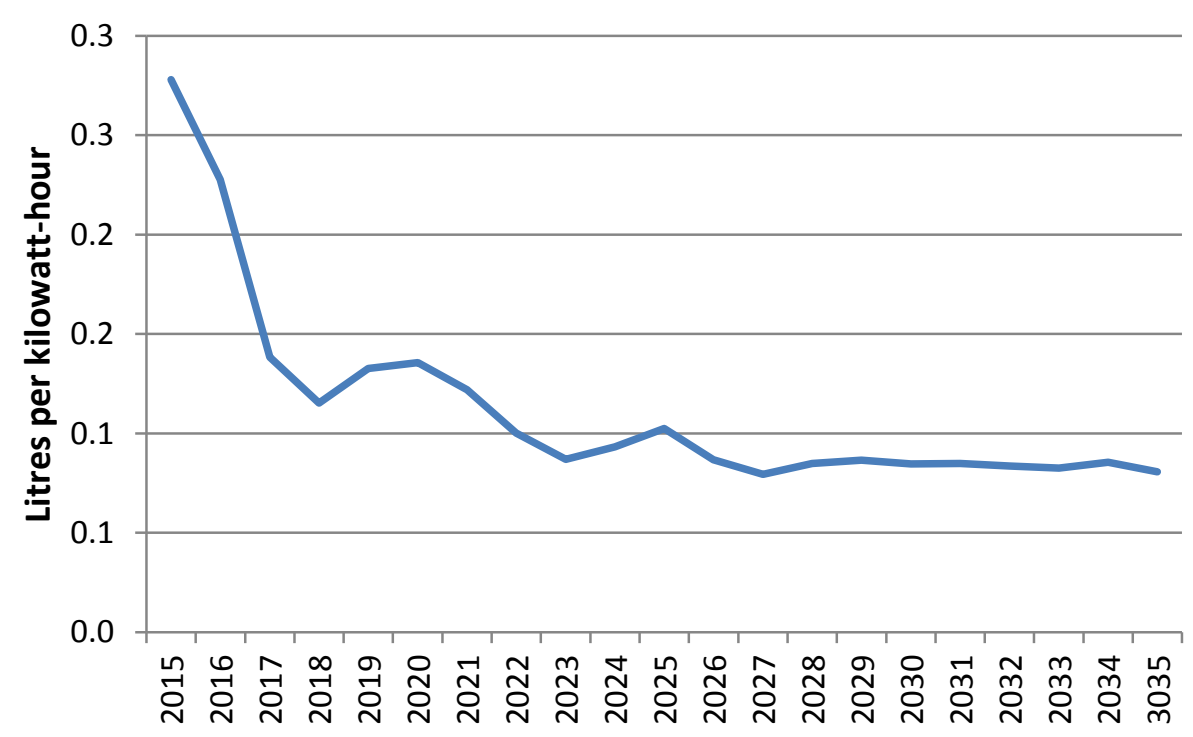

Figure 14: New build power plant water consumption factor projection

The choice of $57 \%$ capacity factor is based on the average capacity factor of coal power plants [54]. However for a supercritical power plant the capacity factor is expected to reach $80 \%$ once all units are fully operational. The generation output is projected based on the addition of $800 \mathrm{MW}$ units added each year starting from 2015 and 2016 for Medupi and Kusile respectively and being operated with a capacity factor of $57 \%$ which is the average capacity factor for modern supercritical power plants. Total water consumption is then determined from generation output and water consumption factor and depicted in Figure 15. 


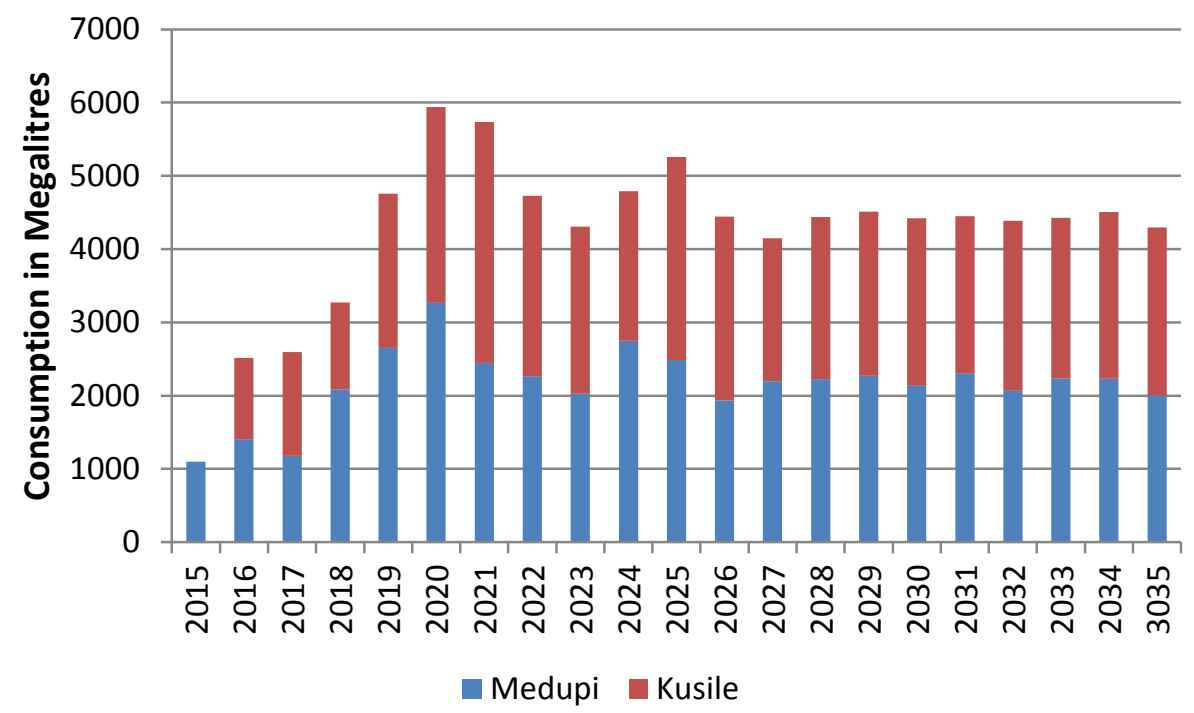

Figure 15: New build power plant total water consumption projection

The initial increase in water consumption in dry cooled power plants is associated with, initial furbishment water usage before full commissioning, being added into total water usage.

\subsection{Combined cases}

Having analysed the various types of power plants based on cooling technology, technology type and periods of operation, a combined water consumption profile can be constructed. Figure 16 provides the consumption factor projection for the various categories of technologies and power plant profiles.

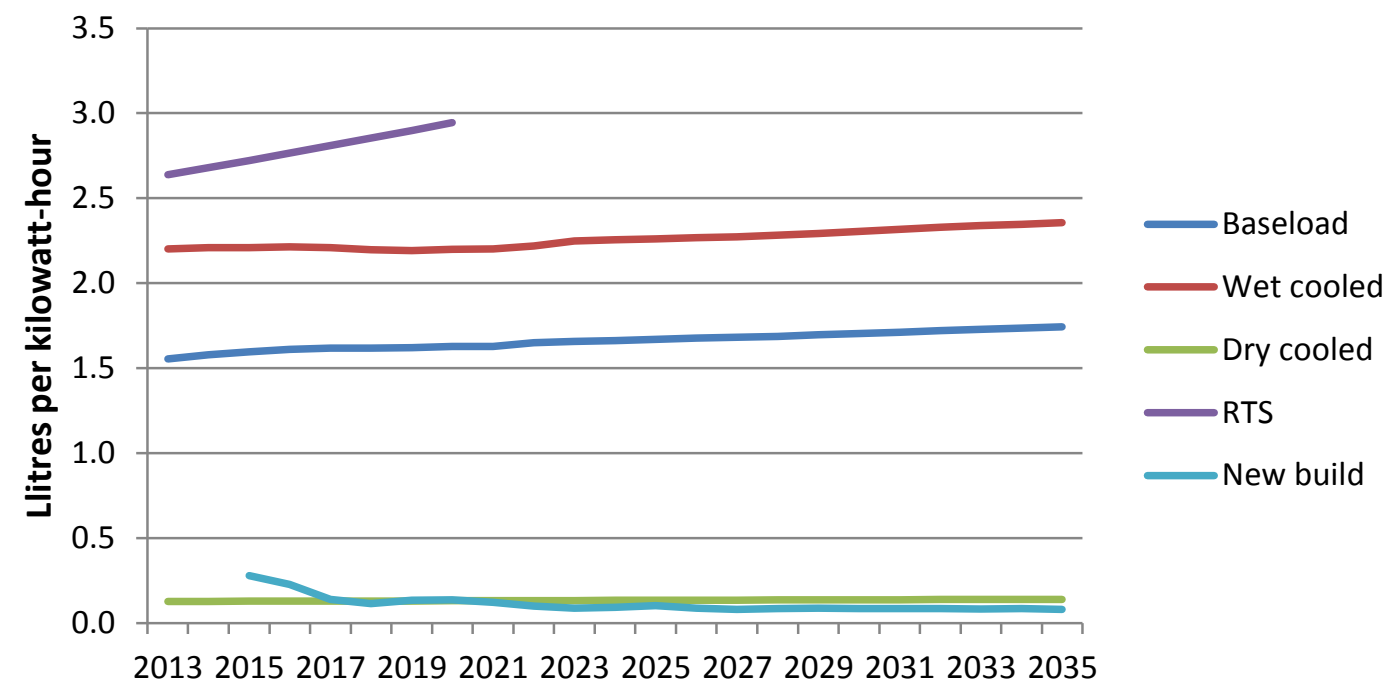

Figure 16: Combined water consumption factor projection

It is important to note that the base load projection shown in the figure is an average of the dry cooled and wet cooled base load power plants. The RTS consumption factor profile is significant higher when compared with other technology types. Therefore it should be recognised that that the RTS fleet, though vital in supplying peak demand capacity, is an added burden on the water consumption profile. This fact can be reiterated when observing the total water consumption profile of all coal based power plants as shown in Figure 17. 


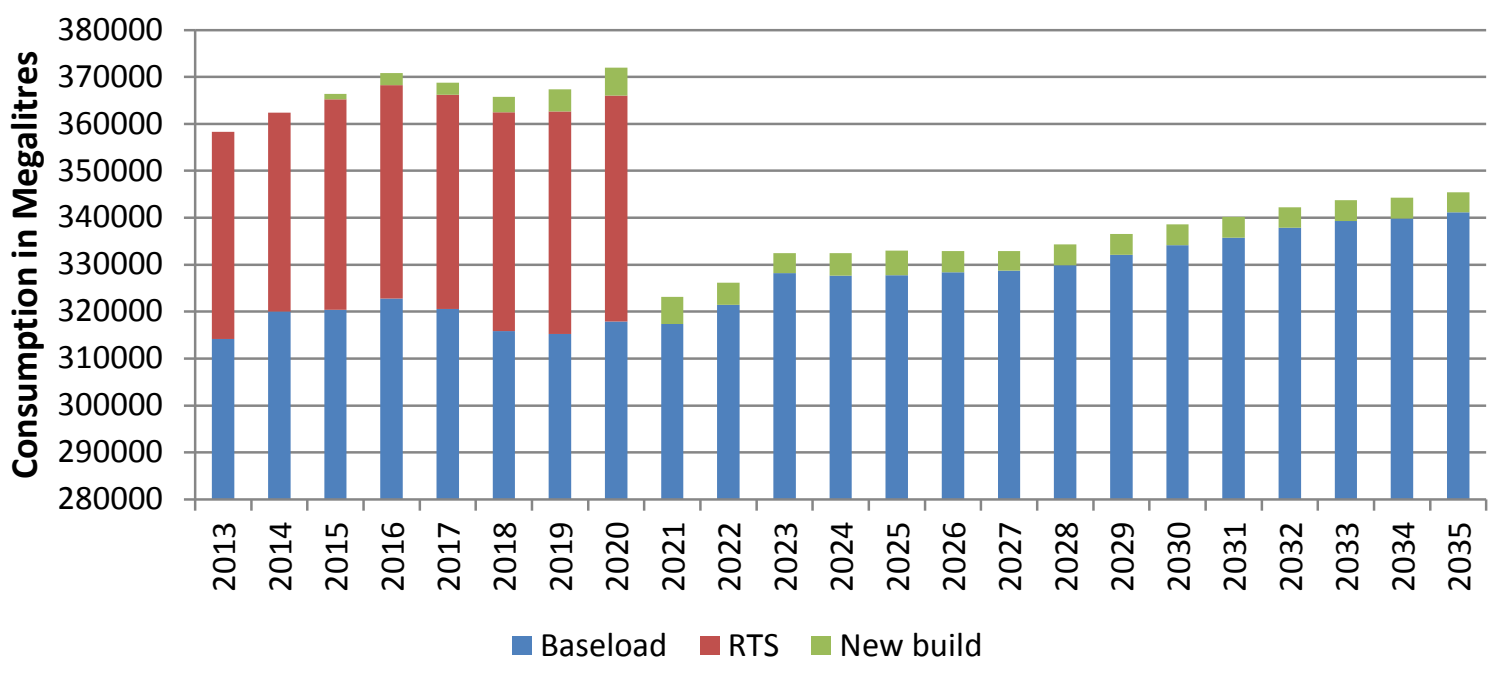

Figure 17: Combined coal power plant water consumption projection

It is essential to note that the $y$ axis in Figure 17 is adjusted to scale to emphasise the contribution of the RTS fleet. It can therefore be observed that retiring the RTS fleet provides a water saving benefit of roughly $13 \%$ although the electrical output contribution of the RTS fleet is roughly between 2 to $3 \%$.

\section{Discussion}

The primary finding has been the determination of the contribution of each power plant to overall water consumption profile. Of the various fleet profiles, the water consumption profile of the RTS is the most significant. Though the RTS fleet has been important in reducing the constraints placed on electricity supply due to increased demand and maintenance, lower performance parameters lead to an increased need of water while supplying electricity during peak hours. The water consumption factor for the RTS fleet is expected to reach $3 \mathrm{l} / \mathrm{kWh}$ by the year 2020. It is vital to note that the RTS fleet has to be decommissioned on a unit by unit basis as soon as the Medupi and Kusile can support the national grid. As shown in Figure 17 total water requirements are expected to increase from roughly 360 gigalitres on current levels to just above 370 gigalitres in 2021. Depending on the retirement of the RTS fleet, water requirements could be reduced to 320 gigalitres. Such a measure would bring a reduction of approximately 40 gigalitres of water per annum, which is roughly the amount of water used by one of the larger power stations such as Kriel, Tutuka, Matla or Lethabo. The shortfall caused in capacity by the retirement of the RTS fleet will be compensated by the phase by phase addition Medupi and Kusile. The new build power plants are expected to consume 4 to 5 gigalitres thereby creating a net saving of 35 gigalitres, when the RTS fleet is decommissioned.

Another important finding is the difference between the weighted average consumption factor and the normal average consumption factor of the entire coal fleet. The weighted average water consumption factor which is measure of the average water consumption based on the percentage of electricity produced by each technology type compared to the average water consumption, is depicted in Figure 18. 


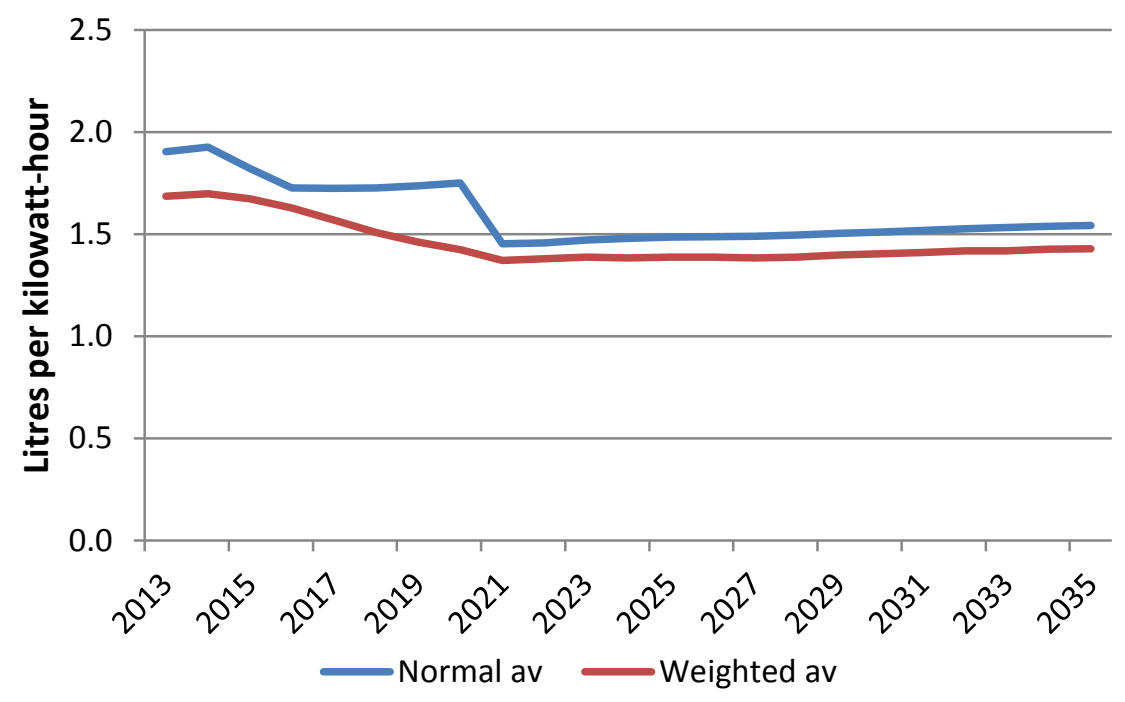

Figure 18: Coal fleet average consumption forecast (weighted vs average)

It can be observed that while the weighted average closely shadows the normal average the variations are more subtle. The variations are negated once the RTS fleet is retired by the year 2020 and the new-build power plants are fully operational. The weighted average can be better understood by analysing the percentage share of the various fleet technologies (Figure 19).

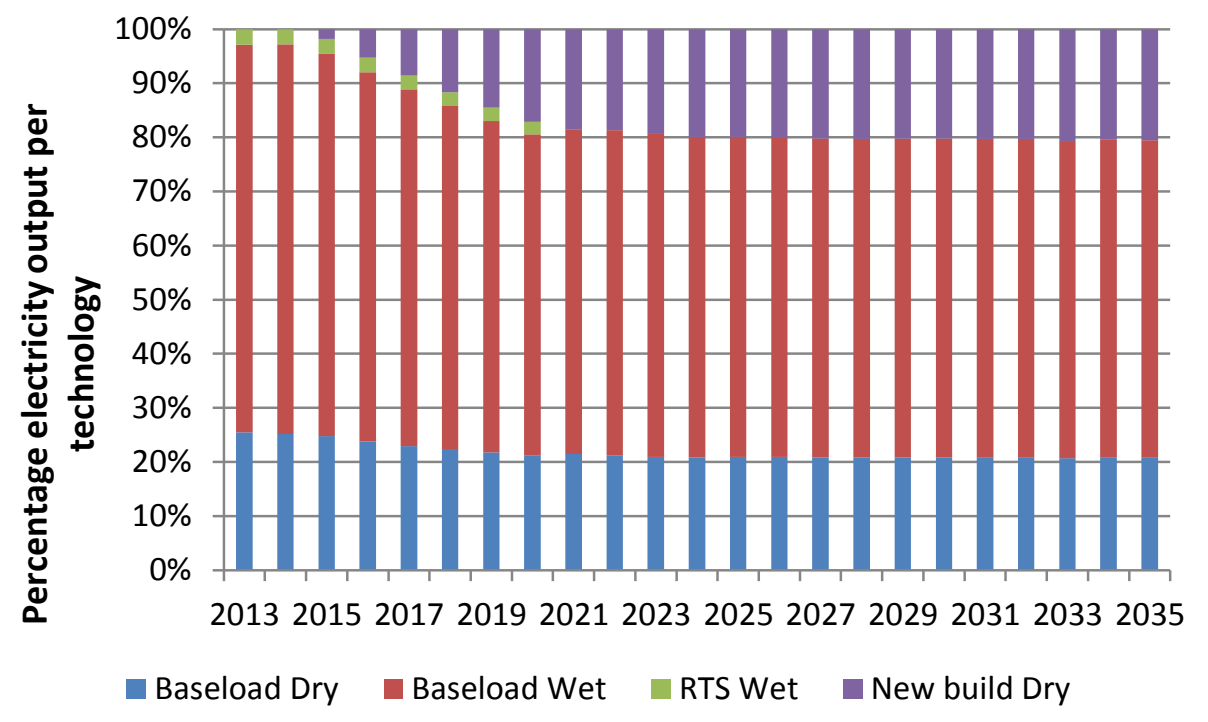

Figure 19: Electricity output per technology fleet forecast

Closer observation shows the weighted average tends to follow the percentage share curve of the wet cooled base load and the new build fleets which have the most dominating variations. In future it is expected that as the newer coal power plants are built and older power plants are retired, the new build fleet will be entirely integrated into the base load fleet thereby changing the coal power plant fleet to be based on a more dry cooling dominated technology.

An important concurrent finding is the forecast of total electricity generated. The forecasts show that the expected output from the coal power plant fleet could reach 260 TWh by the year 2035 . These forecasts 
are in accordance with the expected installed capacity of $36900 \mathrm{MW}$ being operated at a capacity factor of 80\%. The expected forecast is depicted in Figure 20.

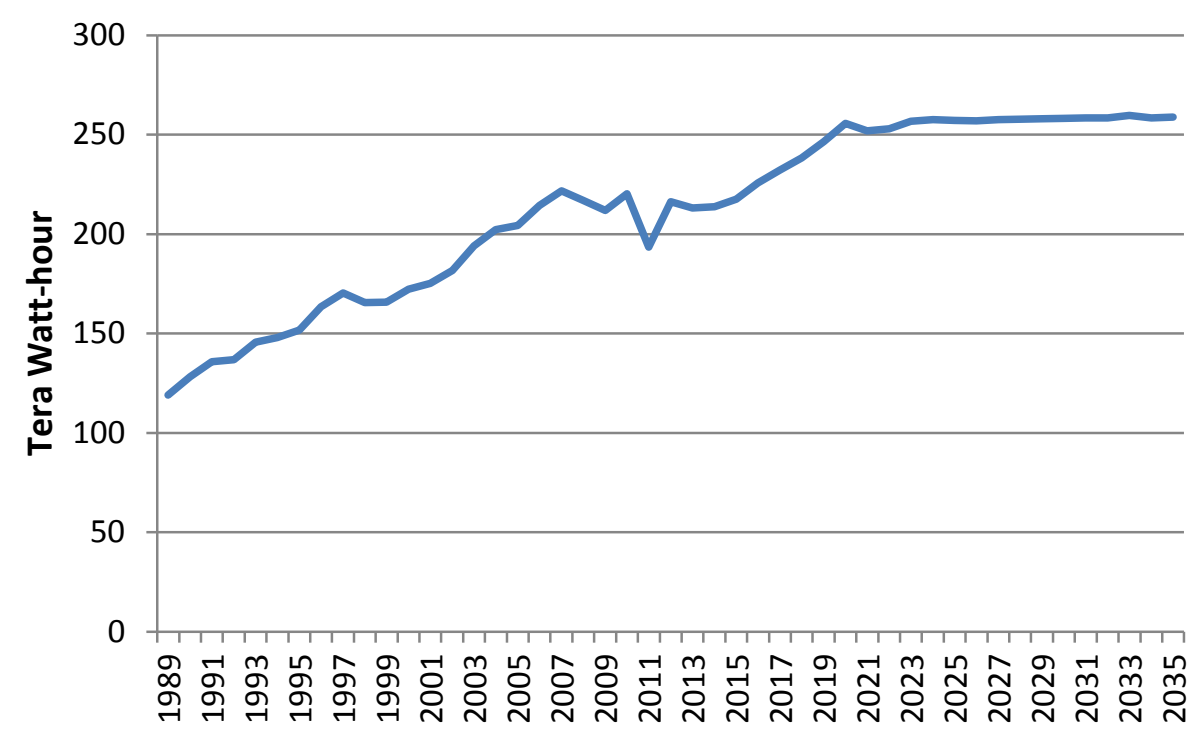

Figure 20: Combined coal fleet generation forecast

The forecasts of total water consumption (Figure 17), average normal/weighted water consumption (Figure 18), electricity generation mix per technology type (Figure 19) and coal fleet generation output (Figure 20) provide a detailed background of the water usage patterns in the coal based electricity generation industry.

Average water consumption forecasts for South Africa's wet cooled power plants (Figure 16) ${ }^{1}$ are higher compared to average water consumption figures for wet recirculating subcritical power plants (as shown in Figure 3) which can be attributed to the decreasing thermal efficiency and increasing age profile of the power plants. However water consumption figures for South Africa's dry cooled power plants (Figure 16) are amongst the best performing in the world (when compared with Figure 3). The lower water usage profiles for dry cooled power plants can be attributed to state of art cooling technologies and lower age profile of these power plants.

Forecasting estimates within this study has been made possible because of the availability of detailed historical water usage patterns. The estimation technique used in the study makes use of average historic water usage data and thermal efficiencies to avoid short term anomalies in data. The mathematical model used in the study makes provision for the incorporation of 10 year average data. The model can be adjusted depending on the availability of short term or long term data sets. However, the drawback of the model is that short term data sets can lead to variations in estimates depending on the anomalies in data sets. The model can also be improved by taking into consideration the type (or quality) of coal burnt in power plants.

\footnotetext{
${ }^{1}$ Values in litres/kWh can be converted to US gallon/MWh using a conversion factor of 264.2
} 


\section{Conclusions and Recommendations}

\subsection{Conclusions and implications}

Based on the findings in section 4 and 5, the following conclusions can be deduced:

$>$ Water consumption factor forecasts of dry cooled power plants (ranging from $0.1 \mathrm{l} / \mathrm{kWh}$ to $0.15 \mathrm{l} / \mathrm{kWh}$ ) are expected to be one order of a magnitude lower than wet cooled power plants (ranging from 2.2 $\mathrm{l} / \mathrm{kWh}$ to $2.4 \mathrm{l} / \mathrm{kWh}$ ).

Implication: Water consumption of wet cooled is bound to increase based on current trends. This can be mainly attributed to the decreasing efficiency of wet cooled power plants. Suggested measures to increase efficiency include actions such as coal and air flow optimisation, heat loss recovery, coal drying, improved coal quality, etc.

Water consumption factor for the RTS fleet is expected to reach $3 \mathrm{l} / \mathrm{kWh}$ by the year 2020.

Implication: The RTS power plant water consumption factor and total water consumption profile are higher compared to the base load fleet primarily because of lower performance parameters, such as reduced efficiency.

$>$ Total water requirements are expected to increase from roughly 360 gigalitres on current levels to just above 370 gigalitres in 2021.

Implication: Depending on the retirement of the RTS fleet, total water requirements could be reduced (by $12 \%$ to $15 \%$ ) to 320 gigalitres. Such a measure would bring a reduction of approximately 40 gigalitres of water per annum, which is roughly the amount of water used by one of the larger wet cooled power stations such as Kriel, Tutuka, Matla or Lethabo.

$>$ Retirement of the RTS fleet has to be performed in conjunction with the commissioning of new build power plants.

Implication: RTS power plants are located in severely water constrained WMAs, Olifants and Inkomati. The gradual retirement of the RTS fleet could provide added water capacity in these WMAs.

$>$ Based on the projection the total base load water consumption will increase from 332 gigalitres in 2013 to roughly 370.5 gigalitres during 2035 .

Implication: The new build power plants that will be using dry cooling technologies are expected to perform more efficiently than the existing dry cooled power plants because of the use of super critical boilers.

\subsection{Recommendations for future work}

Based on the conclusions certain areas of scope, that will augment decision making in electricity based water usage include:

$>$ Credible and verifiable assessment of water usage patterns for new coal technologies.

$>$ Mapping of water usage of coal power plants in comparison with water inventories in water deficient WMAs.

$>$ Impact of emission mitigating technologies on water usage.

$>$ Estimation of water usage patterns in renewable energy technologies.

Further analysis and research in the above areas will provide an improved inventory of water consumption technologies associated with electricity generation. 
The South African Coal Roadmap [55] provides a multi-scenario analysis of the future possibilities and interventions in the local coal industry. The coal roadmap proposes four possible routes ranging from business as usual (which include life extensions to the current fleet) to South Africa leading the world in reducing coal footprint (by employing ultra-super critical power stations and UCG, cyclic PF and FBC based technologies). South Africa predominantly will have to employ a route that is a combination of all scenarios in order to move towards a less coal intensive society while trying to negate the challenges encountered in supply and demand.

Proposed new coal technologies such as UCG and FBC technologies are expected to lower water usage and emissions. The risk associated with UCG technology, where very deep coal seams are burnt underground, is the contamination of underground water reserves [56]. Eskom's Majuba UCG pilot plant is a pioneering project in this technology which receives little public attention because of proprietary concerns [57]. FBC technologies are proposed to be viable for the Waterberg coal field which has large reserves of high ash and low-calorific value coal [55]. On the other hand emission reduction mechanisms such as retrofitting existing power plants with FGD are expected to increase the water footprint of power plants. Eskom has conducted a number of feasibility studies into the water consumption factors of some of the advanced technologies, as shown in Table 5 [58].

Table 5: Indicative water consumption factor for new coal technologies

\begin{tabular}{|l|l|}
\hline Technology Type & Water consumption (I/kWh) \\
\hline Pulverised fuel with FGD & 0.25 \\
\hline Pulverised fuel with carbon capture storage & 0.1 \\
\hline Fluidised bed coal & 0.16 \\
\hline
\end{tabular}

Source: [58]

Because of the lack of actual operational figures, these values can be used for conclusive forecasting only after thorough consultation and verification. To add to the uncertainty, the physical location of the coal power plant (which affects factors such as humidity, evaporation, altitude, etc.) is an important consideration when operational water consumption has to be estimated.

\subsection{Recommendations for planning and implementation}

The majority of South Africa's WMAs are under severe duress. This issue gets worse when taking into account the fact that most of the coal based power plants are within regions partially or severely constrained in terms of water. The following comments can be highlighted in order to enable decisionmaking.

$>$ Eskom's RTS power plants namely Camden, Komati and Grootvlei which are water intensive power plants are located in the severely constrained WMAs namely, Olifants and Inkomati.

$>$ The savings of roughly 35 gigalitres associated with the decommissioning of the RTS fleet and operation of the new build power plants Medupi and Kusile, could account for almost $15 \%$ of the forecasted deficit of 234 gigalitres by 2025 .

$>$ While Medupi is located in the moderately constrained WMA of Limpopo, Kusile is located in the severely constrained Olifants WMA. Therefore Kusile will have a larger water saving impact within the respective WMA.

> The role of coal in electricity generation will be a dominant factor up until locally available resources start to diminish. However, technologies that utilise water efficiently will have to play a more dominant role in order to preserve national water security. 
Measures aimed towards increasing the efficiency of the RTS or gradual decommissioning could bring considerable changes to the forecasted WMA deficits. However decommissioning of the RTS fleet has to be done in concurrence with the commissioning of new build power plants. Additionally the socio-economic costs and benefits related to decommissioning inefficient power plants and switching to less water intensive power generation have to be carefully considered. The financial implications for the utility and the country as a whole have to be deliberated before large utility scale technologies are implemented.

South Africa as a country will have to adapt to water shortages in the near to medium future, as discussed in the introductory section. An inherent lack of abundant freshwater resources, coupled with increasing populations and changing rainfall patterns are bound to create a need for efficient and innovative changes in water usage. Though the agricultural sector is the predominant consumer of freshwater resources, the industrial and power generation sector also have considerable water usage footprints.

South Africa's electricity generation needs are bound to evolve in a manner that is dependent on numerous socio-economic factors such as economic growth, population growth, industrial strength, foreign direct investment, commodity prices, employment and a host of other factors. The most important element that cannot be disputed is the fact that at present South Africa's electricity availability is constrained which at current levels could adversely affect the economic growth of the nation. In order to stimulate production and remain vibrant as an economy, affordable and reliable supply of electricity is paramount.

\section{Acknowledgments:}

The authors would like to thank the Water Research Commission (Pretoria, South Africa) for the funding and oversight provided to complete the research. The authors would also like to thank Eskom for making historical water usage data available. The authors are also grateful for the feedback received during the International Conference of Applied Energy, 2015, which has helped in improving the results of the research.

\section{References}

[1] The Atlantic Council. A Marshall plan for energy and water supply in developing countries. Washington DC, USA: 2005.

[2] Feeley TJ, Skone TJ, Stiegel GJ, McNemar A, Nemeth M, Schimmoller B, et al. Water: A critical resource in the thermoelectric power industry. Energy 2008;33:1-11. doi:10.1016/j.energy.2007.08.007.

[3] Hamiche AM, Stambouli AB, Flazi S. A review on the water and energy sectors in Algeria: Current forecasts, scenario and sustainability issues. Renew Sustain Energy Rev 2015;41:261-76. doi:10.1016/j.rser.2014.08.024.

[4] Gorjian S, Ghobadian B. Solar desalination: A sustainable solution to water crisis in Iran. Renew Sustain Energy Rev 2015;48:571-84. doi:10.1016/j.rser.2015.04.009.

[5] Xin L, Feng K, Siu YL, Hubacek K. Challenges faced when energy meets water: $\mathrm{CO} 2$ and water implications of power generation in inner Mongolia of China. Renew Sustain Energy Rev 2015;45:419-30.

doi:10.1016/j.rser.2015.01.070.

[6] Feng K, Hubacek K, Siu YL, Li X. The energy and water nexus in Chinese electricity production: a hybrid life cycle analysis. Renew Sustain Energy Rev 2014;39:342-55. doi:10.1016/j.rser.2014.07.080.

[7] De Wet H. The Environmental Handbook: a guide to green business in South Africa 2nd ed. 2010. 
Turton A. Three Strategic Water Quality Challenges that Decision-Makers Need to Know About and How the CSIR Should Respond. Keynote Address CSIR Conf. “Science Real Relev. 18 Novemb. 2008, Pretoria, CSIR Rep. No. CSIR/ NRE/WR/EXP/2008/0160/A, 2008, p. 28.

[9] World Bank South Africa Data 2010. data.worldbank.org/country/south-africa (accessed October 27, 2014).

[10] Department of Water Affairs and Forestry SA. National Water Resource Strategy. 2004.

[11] Van Vuuren L. The State of Water in South Africa - Are we Heading for a CRISIS? vol. September. 2009.

[12] Wong J. The Green Leap Forward 2009. greenleapforward.com/2009/02/17/chinas-new-water-efficiencytargets-and-implications-for-food-and-energy/ (accessed October 25, 2014).

[13] Department of Water Affairs, Government Printers. National Water Resource Strategy. Pretoria: 2013.

[14] Wit M De, Stankiewicz J. Changes in Surface Water Supply Across Africa with Predicted Climate Change. Science (80- ) 2011;1917. doi:10.1126/science.1119929.

[15] Suzan Oelofse SW. A CSIR perspective on water in South Africa 2010. 2010. doi:CSIR Report No. CSIR/NRE/PW/IR/2011/0012/A.

[16] Addams L, Boccaletti G, Kerlin M, Stuchtey M. Charting Our Water Future - Economic frameworks to inform decision-making. vol. 21. 2009. doi:2010-07-25.

[17] (SSA) SSA. National Accounts: Water Management Areas in South Africa. 2010.

[18] Gleick PH. Water and Energy. Annu Rev Energy Environ 1994;19:267-99. doi:10.1146/annurev.energy.19.1.267.

[19] Yang J, Yamazaki A. Water and Energy Nexus : A Literature Review. 2013.

[20] World Bank South Africa Data 2014. http://databank.worldbank.org/data/views/reports/tableview.aspx?isshared =true\# (accessed April 27, 2014).

[21] Kenny JF, Barber NL, Hutson SS, Linsey KS, Lovelace JK, Maupin MA. Estimated Use of Water in the United States in 2005. 2005.

[22] Barroso LA, Rudrick H, Sensfuss F, Linares P. The Green Effect. Power Energy Mag IEEE 2010;8:22-35. doi:10.1109/MPE.2010.937595.

[23] Rutberg M. Modeling water use at thermoelectric power plants. 2012.

[24] Anderson S. Idaho Committee adopts moratorium on coal power. Reuters News Serv 2006.

[25] Martin AD. Water Footprint of Electric Power Generation : Modeling its use and analyzing options for a waterscarce future. 2012. doi:10.1021/es802162x.

[26] GAO. Energy-Water Nexus: Improvements to Federal Water Use Data Would Increase Understanding of Trends in Power Plant Water Use. 2009.

[27] Henderson P a., Seaby MHR, Super R, Hankovszky A, Aboulhosn D, Bressett H, et al. Giant Fish Blenders : How Power Plants Kill Fish And Damage Our Waterways. Sierra Club 2011:1-17. 
[28] U.S. Department of Energy. Electricity reliability impacts of a mandatory cooling tower rule for existing steam generation units. 2008.

[29] Mielke E, Diaz Anadon L, Narayanamurti V. Water Consumption of Energy Resource Extraction, Processing, and Conversion: A review of the lierature for estimates of water intensity of energy-resource extraction, processing to fuels, and conversion to electricity. 2010.

[30] U.S. Department of Energy. Energy Demands on Water Resources: Report to Congress on the Interdependency of Energy and Water. 2006.

[31] EPRI. Program on Technology Innovation: Power Generation and Water Sustainability. Palo Alto, California: 2007.

[32] EPRI. Water Use for Electric Power Generation. vol. 1014026. Palo Alto, California: 2008.

[33] Barker B. Running dry at the power plant. EPRI Summer J 2007:26-35.

[34] Mittal A, Gaffigan M. Energy-Water Nexus. Washington DC, USA: 2009.

[35] Macknick J, Newmark R, Heath G. A Review of Operational Water Consumption and Withdrawal Factors for Electricity Generating Technologies A Review of Operational Water Consumption and Withdrawal Factors for Electrici.pdf. Colorado, USA: 2011.

[36] Yang X, Dziegielewski B. Water use by thermoelectric power plants in the United States. J Am Water Resour Assoc 2007;43:160-9. doi:10.1111/j.1752-1688.2007.00013.x.

[37] NETL. Power Plant Water Usage and Loss Study. 2007.

[38] Chandel MK, Pratson LF, Jackson RB. The potential impacts of climate-change policy on freshwater use in thermoelectric power generation. Energy Policy 2011;39:6234-42. doi:10.1016/j.enpol.2011.07.022.

[39] Zemlick K, Tidwell VC, Roberts BL, Castillo CR. Suitability Assessment of Non-Potable Water to Meet the Electricity Generation Demands in 2030. J Contemp Water Res Educ 2013:95-105.

[40] van Vliet MTH, Vögele S, Rübbelke D. Water constraints on European power supply under climate change: impacts on electricity prices. Environ Res Lett 2013;8:035010. doi:10.1088/1748-9326/8/3/035010.

[41] Ruebbelke D, Voegele S. Impacts of climate change on European critical infrastructures: The case of the power sector. Environ Sci Policy 2011;14:53-63. doi:10.1016/j.envsci.2010.10.007.

[42] King CW, Duncan I, Webber ME. Water Demand Projections for Power Generation in Texas. 2008.

[43] NETL. Estimating Freshwater Needs to Meet Future Thermoelectric Generation Requirements: 2010 Update. 2009. doi:DOE/NETL-400/2010/1339.

[44] NETL. Estimating Freshwater Needs to Meet Future Thermoelectric Generation Requirements: 2013 Update. 2013. doi:DOE/NETL-400/2010/1339.

[45] Jansen A, Schulz C-E. Water Demand and the Urban Poor: A Study of the Factors Influencing Water Consumption Among Households in Cape Town, South Africa. South African J Econ 2006. 
[46] Rousseau PG. Demand side management for water heating installations in South African commercial buildings. Int J Energy Res 2001;16:45-317. doi:10.1002/er.680.

[47] Eskom. Supplementary and divisional report. Sandton, South Africa: 2014.

[48] Eskom. Water management- COP17 fact sheet. Sandton, South Africa: 2010.

[49] Wassung N. Water scarcity and electricity generation in South Africa. 2010.

[50] Department of Energy. Integrated Resource Plan For Electricity (IRP) 2010-2030 Update Report 2013. 2013.

[51] Box GEP, Jenkins GM, and Reinsel GC. Time Series Analysis: Forecasting and Control. Fourth edition. 2013. doi:10.1007/SpringerReference_6246.

[52] Agencia Internacional de Energía. Technology Roadmap. High-Efficiency, Low-Emission Coal-Fired Power Generation. 2012.

[53] Eskom. Eskom Internal Data 2014.

[54] Department of Energy \& Climate Change. UK National Statistics Electricity: Chapter 5, Digest of United Kingdom Energy Statistics (DUKES). 2015.

[55] SANEDI. South African Coal Roadmap. Sandton, South Africa: 2013.

[56] Atkins Consultants. Review of environmental issues of underground coal gasification. 2004. doi:Report No: Coal R272 DTI/Pub URN 04/1880.

[57] Eskom. Underground coal gasification 2008. http://www.ee.co.za/wp-content/uploads/legacy/Eskom coal gasification.pdf (accessed November 28, 2014).

[58] Department of Energy South Africa. Water - 2010 Input Parameter Data Sheet ( Externality ). Pretoria: 2010. 